\title{
Synthesis and Biological Evaluation of Simplified Pironetin Analogues with Modifications in the Side Chain and the Lactone Ring
}

\author{
Steven Roldán, ${ }^{\text {a,b }}$ Adrià Cardona, ${ }^{\text {a,c }}$ Juan Murga, ${ }^{* a}$ Eva Falomir, ${ }^{a}$ Miguel Carda, ${ }^{* a}$ and J. Alberto Marco ${ }^{d}$ \\ ${ }^{a}$ Depart. de Q. Inorgánica y Orgánica, Univ. Jaume I, Castellón, E-12071 Castellón, Spain. E-mail: jmurga@uji.es \\ ${ }^{b}$ Current address: Depart. de Química. Univ.de Girona, E-17003 Girona, Spain. E-mail: steven.roldan@edg.edu \\ ${ }^{c}$ Current address: Depart. de Q. Analítica y Q. Orgánica. Univ. Rovira i Virgili, E-43007 Tarragona, Spain. E-mail adrian.cardona@urv.cat \\ ${ }^{d}$ Depart. de Q. Orgánica, Univ. de Valencia, E-46100 Burjassot, Valencia, Spain. E-mail: alberto.marco@uv.es
}

The preparation of several new analogues of the natural dihydropyrone pironetin is described.

They differ from the natural product mainly in the nature of the side chain and the lactone ring. Their cytotoxic activity has been measured. In addition, their interaction with tubulin and their ability to inhibit the secretion of the vascular endothelial growth factor (VEGF) and the expression of angiogenesis and telomerase-related genes have been determined. Some of the compounds have been found active in some of these biological properties.

\section{Introduction}

It is widely known that cancer, one leading cause of death in developed countries, may be induced by a plethora of both external and internal factors, including genetic mutations. Accordingly, a number of types of therapeutic attack has been investigated. ${ }^{1}$ One of these involves the use of cytotoxic drugs, which exert their effect in many cases by means of inducing various mechanisms of cell death. ${ }^{2}$ As a matter of fact, many of such drugs owe this property to interaction with the microtubule network. Microtubules are dynamic polymers that play a central role in a number of cellular processes, most particularly cell division, as they are key constituents of the mitotic spindle. ${ }^{3}$ Microtubules are constituted of a protein named tubulin, the functional form of which, and the most abundant component, is a heterodimer formed through noncovalent binding of two monomeric constituents, called $\alpha$ and $\beta$-tubulin. For cell division to occur in a normal way, microtubules must be in a constant state of formation and disruption, a process named microtubule dynamic instability. ${ }^{4}$ Molecules which influence microtubule instability will also influence the cell division process, not only of normal cells but also of tumoral ones. Therefore, it is not surprising that tubulin-binding molecules (TBMs) constitute a very important class of anticancer agents. ${ }^{5}$

TBM are able to interfere with microtubule assembly and functions, either by causing disruption of the microtubules or else through their stabilization. Most of the hitherto described active drugs are natural products or derivatives thereof. ${ }^{6}$ Major drugs can already be found on the market and many other promising compounds are in clinical trials.

TBM may be divided in two broad categories, those that bind to $\alpha$-tubulin and those that bind to $\beta$-tubulin. The latter group is presently by far the most numerous and contains products which cause either disruption ${ }^{7}$ or stabilization ${ }^{8}$ of microtubules. The number of products that bind to $\alpha$-tubulin is, however, very small, ${ }^{9}$ the naturally occurring 5,6-dihydro$\alpha$-pyrone pironetin (Figure 1) being the first-reported example. Pironetin is a potent inhibitor of tubulin assembly and has been found to arrest cell cycle progression in the
G2/M phase. ${ }^{10}$ This feature has motivated a number of groups to undertake total syntheses of this natural compound. ${ }^{11}$ It is worth mentioning here that 5,6-dihydro- $\alpha$-pyrones constitute an ample group of natural products endowed with a broad variety of pharmacologically useful properties, most likely related to the presence of the Michael acceptor moiety in the pyrone ring. ${ }^{12}$

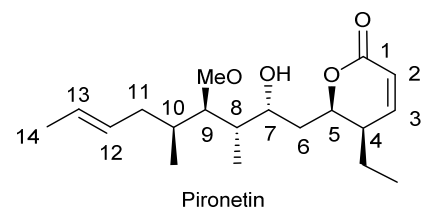

Figure 1 Structure of pironetin, a highly cytotoxic natural pyrone.

Some structure-activity (SAR) studies on pironetin have been reported. ${ }^{10}$ These studies have shown that the presence of the conjugated double bond in the lactone ring and of the hydroxyl group at C-9, either free or methylated, are essential for the biological activity. ${ }^{9}$ The epoxidation of the $\mathrm{C} 12=\mathrm{C} 13$ double bond has been shown to cause a decrease in the activity but this may perhaps represent a negative feature of the oxirane ring, rather than a strict need of this $\mathrm{C}=\mathrm{C}$ bond.

As a member of the up to now small group of products that bind to $\alpha$-tubulin, pironetin constitutes a pharmacologically interesting target. Thus, a key purpose of our research is the preparation of pironetin analogues that retain a substantial proportion of the biological activity of the natural metabolite while displaying a more simplified structure. In order to develop SAR studies based upon the pironetin framework, we designed several years $\operatorname{ago}^{13}$ a simplified model structure where all elements that had not yet proven to be essential for the biological activity were removed. The target structures I/II are schematically shown in Figure 2. The elements that were maintained are the conjugated dihydropyrone ring and the side chain with the methoxy group at C-9. The hydroxyl group at C-7 was removed in some substrates (I) and retained in others (II), in order to see its influence on the activity. All alkyl pendants (methyl groups at C-8 and C-10, ethyl at C-4) and the isolated $\mathrm{C} 12-\mathrm{C} 13$ double bond were removed. The 
configurations of the two/three remaining stereocentres were then varied in a systematic way. Thus, all four possible stereoisomers with general constitution I, with no hydroxyl group at C-7, were prepared. Likewise, all eight stereoisomers exhibiting general structure II, with a hydroxyl group at C-7, were synthesized. Subsequently, the cytotoxic activity of these analogues and their interactions with tubulin were investigated. $^{13}$

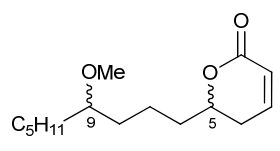

I

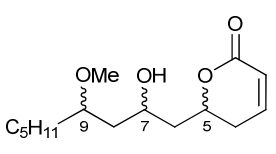

II
Figure 2 General structures of the first generation of simplified pironetin analogues (ref. 13).

In continuation of this line of research, we concentrated our attention on the importance of the alkyl pendants in the pironetin molecule for the biological properties of the natural compound. In line with this reasoning, we prepared the six pironetin analogues III-VIII (Fig. 3). In all these compounds, the configurations at the oxygenated carbons C-5, C-7 and C-9 are as in natural pironetin. With respect to general structure II (Fig. 2), compounds III and IV contain an additional methyl residue at $\mathrm{C}-10$ with either configuration, whereas in compounds $\mathbf{V}$ and VI, the extra methyl pendant is allocated at C-8. Finally, compounds VII and VIII display an extra alkyl residue (methyl or ethyl) at $\mathrm{C}-4$, in both cases with the same configuration as in natural pironetin. ${ }^{14}$

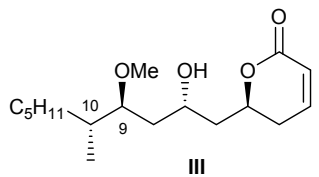<smiles>CO[C@H](C[C@@H](O)C[C@@H]1CC=CC(=O)O1)[C@@H](C)[15CH3]</smiles><smiles>[CH][C@@H](OC)[C@H](C)[C@@H](O)CC1CC=CC(=O)O1</smiles><smiles>CCCCC[C@@H](C[C@@H](O)C[C@@H]1OC(=O)C=C[C@H]1C)OC</smiles>

VII<smiles>CCCCCCC[C@@H](OC)[C@H](C)[C@H](O)C[C@H]1CC=CC(=O)O1</smiles><smiles>CCCCCCCCC(C[C@H](O)C[C@H]1OC(=O)C=C[C@H]1CC)OC</smiles>

Figure 3 Structures III-VIII of the second series of pironetin analogues (ref. 13).

The cytotoxic activities of pironetin analogues III-VIII were then investigated. Most compounds proved cytotoxic in the low micromolar range, therefore about two-three orders of magnitude less active than pironetin itself. ${ }^{14}$ These results suggest that all alkyl pendants are important for the full biological activity, this being most likely due to the fact that the alkyl groups restrict the conformational mobility of the molecule and reduce the number of available conformations. ${ }^{15,16}$ This in turn makes more probable that the molecule adopts a shape that fits better into the active site of $\alpha$-tubulin.

In view of these results, we decided to prepare a new group of pironetin analogues with a higher degree of alkylation in the side chain but still retaining a simplified structure. Figure 4 shows the eight compounds we have prepared and evaluated for their biological properties.
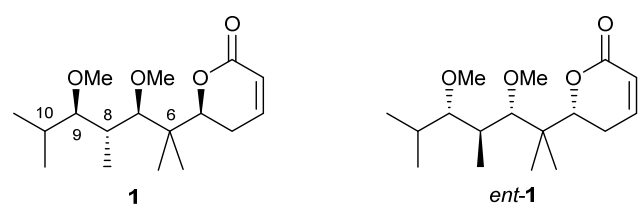<smiles>CO[C@H]([C@@H](C)C(C)C)C(C)(C)[C@H]1CC=CC(=O)O1</smiles><smiles>CO[C@H](C(C)C)[C@@H](C)C(C)(C)[C@H]1CC=CC(=O)O1</smiles><smiles>CO[C@H]([C@@H](C)[C@@H](C)C(C)(C)C)[C@H]1C=CC(=O)O1</smiles><smiles>CO[C@H](C(C)C)[C@@H](C)[C@H](C)C(C)(C)[C@H]1C=CC(=O)O1</smiles><smiles>CO[C@H]([C@@H](C)[C@@H](C)C(C)(C)C)[C@H]1C=CC(=O)O1</smiles><smiles>CO[C@H](C(C)C)[C@@H](C)[C@H](C)C(C)(C)[C@H]1C=CC(=O)O1</smiles>

Figure 4 Structures of compounds of the third series of pironetin analogues (this work).

In comparison to pironetin, pyrones $\mathbf{1}$, ent $\mathbf{- 1 , 2}$ and ent-2 in Fig. 4 display a shorter carbon chain, two stereocentres less (C-4 and C-10 in pironetin numbering) and an additional gemdimethyl moiety (at C-6 in pironetin numbering). Furthermore, and in order to investigate the importance of the lactone ring size, analogues 3, ent-3, 4 and ent-4 having a furanone system were also prepared.

In recent times, we have not limited our biological investigations on bioactive molecules to solely measurements of their cytotoxic activity, expressed as $\mathrm{IC}_{50}$ values. Indeed, while mechanisms of anticancer activity are often related to interference with microtubule assembly and functions, other mechanisms may also be operative. In most solid tumors, for example, angiogenesis is an important process for tumor growth and metastasis. Many different mediators are involved in this process, including the vascular endothelial growth factor (VEGF), which has been shown to play a critical role in pathological angiogenesis. ${ }^{17}$

Another relevant mechanism in cancer genesis is related to the role of the chromosomal telomers. Most cancer cells exhibit telomerase activity. The latter mantains the length of the telomeres, thus preserving genomic stability. ${ }^{18}$ Telomerase is a ribonucleoprotein composed of two main subunits which, in the case of human beings, are called human telomerase RNA (hTR) and human telomerase protein (hTERT). Many studies have demonstrated that interference in the expression of the $h T E R T$ gene can efficiently inhibit the growth and tumorigenicity of cancer cells, as the hTERT gene is a rate- 
limiting factor in telomerase synthesis and activity. Equally important is the $c-M y c$ gene, which has been found to be amplified in various types of human cancers. The result of the expression of this gene, the c-Myc protein, is a transcriptional factor with an important role in cell proliferation, differentiation, invasion and adhesion of tumor cells. ${ }^{19}$ It is also involved in the activation of $h T E R T$ gene transcription.

Since on one hand tumoral cell secretion of VEGF is an important factor in metastasis and, on the other hand, telomerase is responsible for the inmortality of tumoral cells, the potential multiple ability ${ }^{20}$ of some compounds to perturb microtubule dynamics and, at the same time, to inhibit VEGF secretion by tumoral cells and the expression of the $V E G F$, hTERT and $c-M y c$ genes was considered a goal worth pursuing. For that reason, we have also included the last types of biological activities in our unvestigation of the general pharmacological profile of our compounds.

\section{Results and discussion}

\section{Synthesis of compounds 1-4 and their enantiomers}

For our purposes, we aimed at performing a simple synthetic sequence in which stereochemical complexity is rapidly achieved through a convergent methodology. Thus, the synthesis of compounds 1-4 was carried out as depicted in Scheme 1. Creation of chirality was achieved by means of an adaptation of a published organocatalytic procedure. ${ }^{21}$ Thus, propionaldehyde and isobutyraldehyde were allowed to react in DMF in the presence of D-proline. This gave a crossed aldol product which was subjected in situ to Barbier-type, indium-mediated prenylation to yield diol $\mathbf{5}$ in fair yield and high enantio- and diastereoselectivity. ${ }^{21}$ Methylation to $\mathbf{6}$ was followed by ozonolysis to yield an unstable intermediate aldehyde which, without isolation, was allowed to react with allylmagnesium bromide in THF. This sequence furnished a mixture of diastereoisomeric alcohols 7 and $\mathbf{8}$ (d.r. 2:1), which proved amenable to chromatographic separation. Both compounds were then esterified with acryloyl chloride, and the resulting acrylates, 9 and $\mathbf{1 0}$, were subjected to rutheniumcatalyzed ring-closing metathesis ${ }^{22}$ to afford the target dihydropyranones $\mathbf{1}$ and $\mathbf{2}$, respectively. Their enantiomers ent-1 and ent-2 were obtained by means of an identical synthetic sequence with the only difference of using L-proline as the organocatalyst (see Experimental).

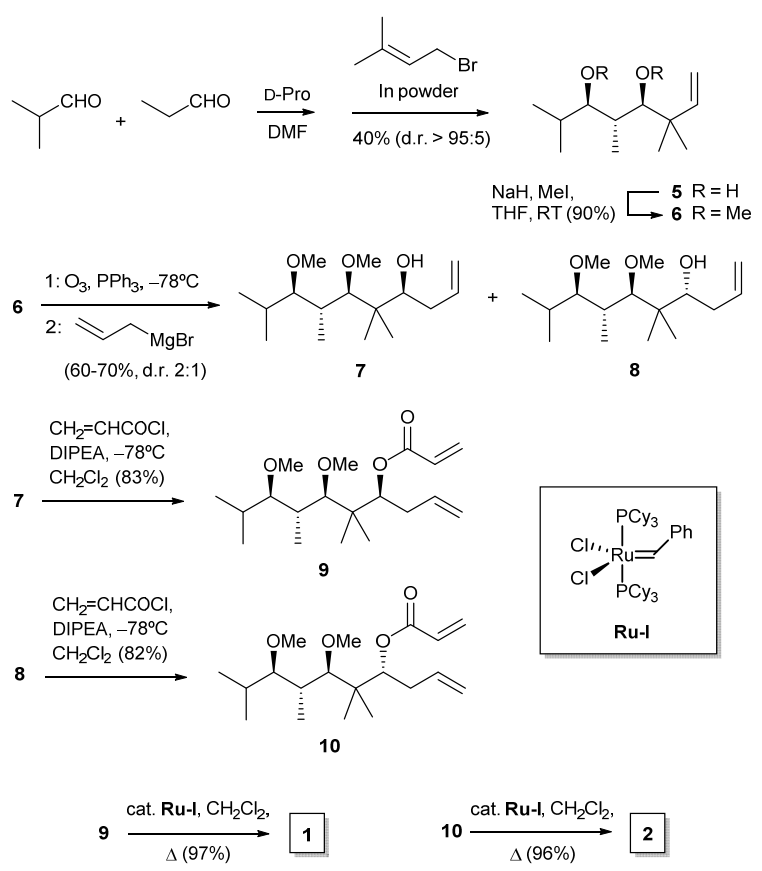

Scheme 1 Synthesis of dihydropyranones 1 and 2. Abbreviations: DPro, D-proline; DIPEA, ethyl $N, N$-diisopropylamine.

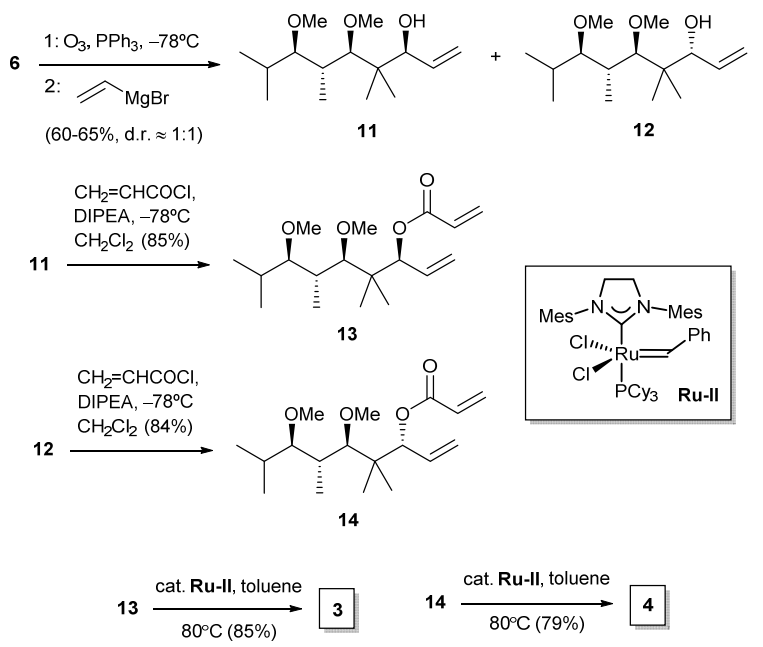

Scheme 2 Synthesis of furanones 3 and 4.

Furanones 3 and $\mathbf{4}$ were prepared by means of a similar reaction sequence starting from olefin 6 (Scheme 2). Thus, the latter compound was subjected to ozonolysis followed by treatment of the crude unstable aldehyde with vinylmagnesium chloride to yield alcohols $\mathbf{1 1}$ and 12. These were then separated and subjected to esterification to acrylates 13 and 14, respectively. Ring-closing metathesis of the latter compounds required the use of a second generation Grubbs ruthenium catalyst ${ }^{22}$ in hot toluene as the solvent, and provided the target furanones $\mathbf{3}$ and $\mathbf{4}$. Their enantiomers ent-3 and ent-4 were obtained from ent-6 alongside the same reaction sequence (see Experimental). 


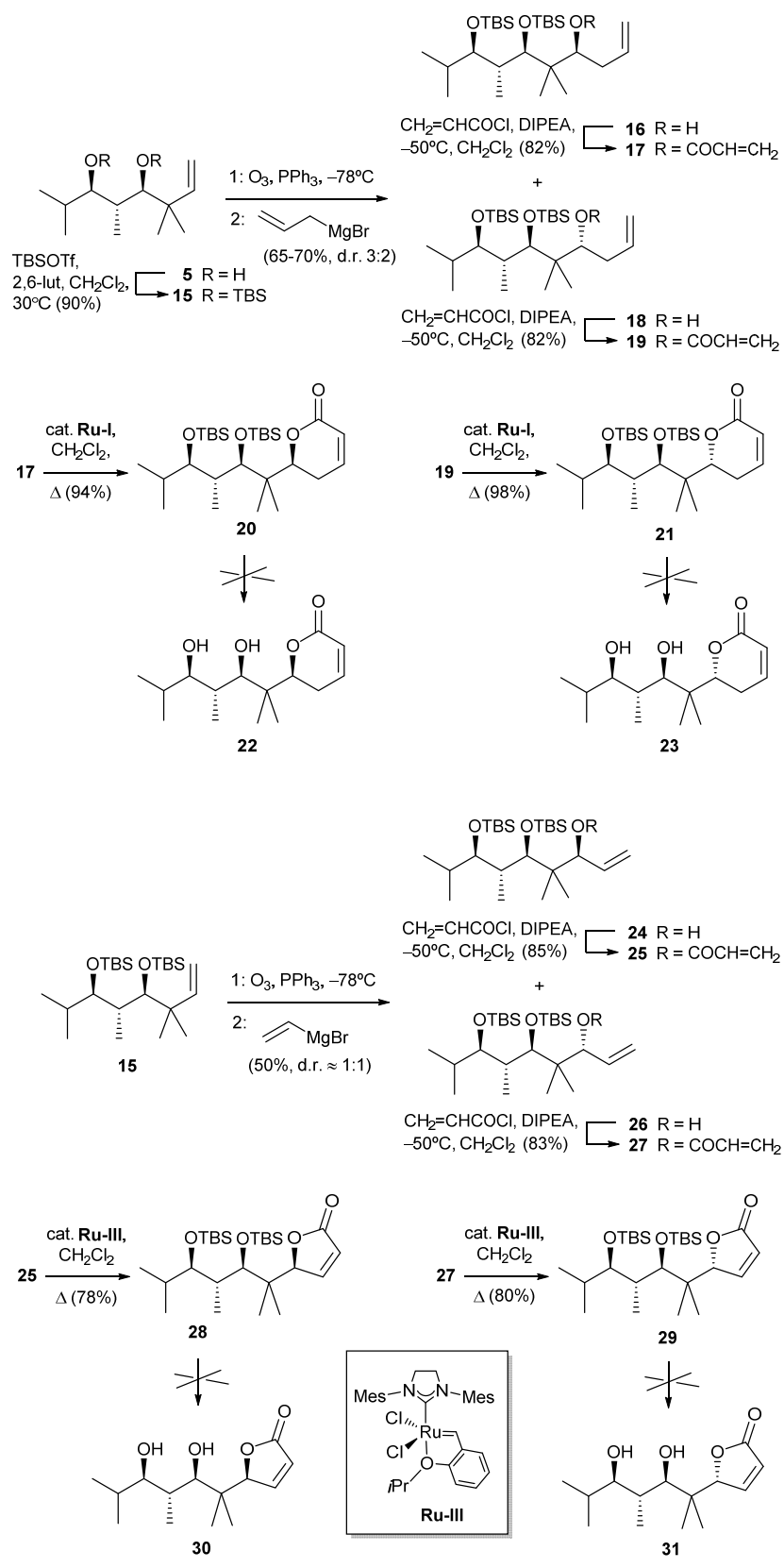

Scheme 3 Attempts at the synthesis of dihydropyranones $\mathbf{2 2}$ and $\mathbf{2 3}$ and furanones 30 and 31. Abbreviation: 2,6-lut, 2,6-lutidine.

In order to check the influence of having hydroxy instead of methoxy groups in the side chain (pironetin and compounds in Fig. 3 have one methoxy group and one hydroxyl group), we also tried to prepare analogues of compounds 1-4 with two hydroxy groups. To that purpose, diol $\mathbf{5}$ was doubly silylated to 15, and the latter subjected to the same ozonolysis/allylation or alternatively ozonolysis/vinylation sequence to yield the diastereoisomeric pairs $\mathbf{1 6 / 1 8}$ and $\mathbf{2 4 / 2 6}$, respectively (Scheme 3). After esterification with acryloyl chloride to $17 / 19$ and $25 / 27$, ring-closing metathesis using in this case a Hoveyda-Grubbs-type ruthenium catalyst ${ }^{22}$ afforded 20/21 and 28/29, respectively. Unfortunately, all attempts at desilylation of the latter compounds under many different conditions to the desired lactones 22, 23, 30 and 31 only led to either no reaction, decomposition or formation of complex inseparable mixtures. ${ }^{23}$

\section{Biological properties of pironetin analogues 1-4 and their enantiomers}

Cellular effects of the compounds. We have determined the $\mathrm{IC}_{50}$ values for pironetin analogues 1-4, and ent-1/ent-4 on five tumoral cell lines: human colorectal adenocarcinoma HT-29 and HTC-116, human breast adenocarcinoma MCF-7, human cervical cancer HeLa and human promyelocytic leukemia HL-60, and compared these values with that of pironetin. Table 1 shows the cytotoxicity values for pironetin $(\mathrm{nM})$ and pironetin analogues expressed as the compound concentration $(\mu \mathrm{M})$ that causes $50 \%$ inhibition of cell growth $\left(\mathrm{IC}_{50}\right)$.

Table 1. $\mathrm{IC}_{50}$ values $(\mu \mathrm{M})$

\section{Comp HT-29 HTC-116 MCF-7 HeLa HL-60}

Piron. $\quad 7.1 \pm 0,4 \mathrm{nM} \quad 8.3 \pm 0.5 \mathrm{nM} \quad 6.8 \pm 0,6 \mathrm{nM} 9.2 \pm 0.8 \mathrm{nM} \quad 12.6 \pm 0.9 \mathrm{nM}$

$\begin{array}{cccccc}1 & 4.2 \pm 0.4 & 30 \pm 1 & 22.25 \pm 0.18 & 38 \pm 3 & 3.4 \pm 0.7 \\ 2 & 28.5 \pm 0.5 & 62 \pm 2 & 21 \pm 2 & 60.5 \pm 0.3 & 4.0 \pm 0.5 \\ \mathbf{3} & >100 & >100 & >100 & 95 \pm 5 & >100 \\ 4 & >100 & >100 & >100 & >100 & >100 \\ \text { ent1 } & 47 \pm 2 & 62.0 \pm 0.6 & 50 \pm 2 & 54.2 \pm 0.4 & 33 \pm 7 \\ & & & & & \\ \text { ent-2 } & 5.9 \pm 0.8 & 36 \pm 1 & 12.9 \pm 0.9 & 53.8 \pm 0.1 & 1.38 \pm 0.15 \\ & & & & & \\ \text { ent-3 } & >100 & >100 & >100 & >100 & >100 \\ & & & & & \\ \text { ent-4 } & >100 & >100 & >100 & & \end{array}$

${ }^{\mathrm{a}} \mathrm{IC}_{50}$ values ( $\mu \mathrm{M}$ for $\mathbf{1 - 4}$, and ent-1/ent-4 and $\mathrm{nM}$ for pironetin) are the mean \pm standard error of three independent experiments.

The first conclusion that can be drawn from the $\mathrm{IC}_{50}$ values is that furanones $\mathbf{3}$ and $\mathbf{4}$ and their respective enantiomers ent3 and ent $\mathbf{4}$ show almost no cytotoxicity. Pyranones did prove cytotoxic in the low micromolar range, thus about two-three orders of magnitude less active than pironetin itself. Among pyranones the most active compounds are $\mathbf{1}$ and ent-2. These two compounds share a common structural feature, the configuration of the lactone stereocenter, which is the same as in pironetin.

Effect of pironetin derivatives on the in vitro microtubule assembly. As pyranone derivatives showed to be cytotoxic we selected them to study their effect on the in vitro microtubule assembly. Figure 5 shows the effects of pyranones 1, 2, ent-1 and ent-2 on the microtubule formation studied by time-resolved turbidity measurements. Blue line shows the effects on the 
microtubule assembly when $25 \mu \mathrm{M}$ of tubulin was reacted in the presence of $20 \mathrm{mM}$ sodium phosphate $(\mathrm{NaPi}), 10 \mathrm{mM} \mathrm{MgCl}_{2}, 1$ mM EGTA, 3.4 M glycerol and $0.1 \mathrm{mM}$ of GTP at $\mathrm{pH}=6.5$. It can be seen that the nucleation phase takes aproximately $18 \mathrm{~min}$. Then elongation phase starts and after 20 min the steady state is reached. When tubulin assembly is carried out in the presence of $27.5 \mu \mathrm{M}$ of paclitaxel, absorbance is immediately increased (orange line) which is in accordance with the behaviour of a drug that promotes tubulin polymerization. Conversely, when tubulin assembly is carried out in the presence of $27.5 \mu \mathrm{M}$ of pironetin, no absorbance is measured throughout the reaction time (green line), which is in accordance with the behaviour of a drug that inhibits tubulin polymerization. When tubulin assembly is carried out in the presence of $27.5 \mu \mathrm{M}$ of each pyranone the dinamic of microtubule formation is quite similar to the one in the ausence of any compound (blue line). It can be inferred from these experiments that, in contrast to pironetin itself, pyranones $\mathbf{1}, \mathbf{2}$, ent-1 and ent-2 have little influence on the process of tubulin polymerization.

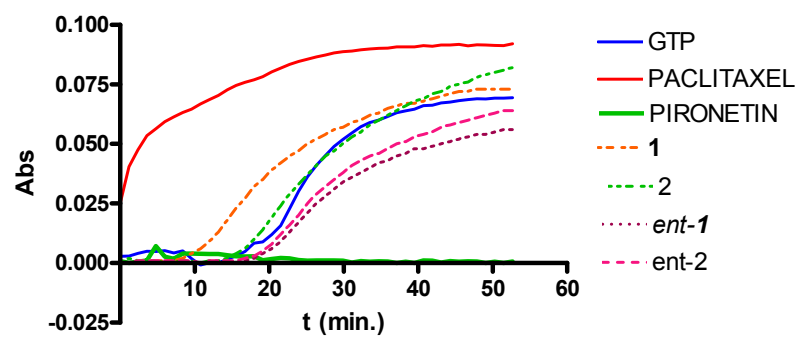

Figure 5.. Effects of colchicine, pironetine and compounds 1, 2, ent-1 and ent-2, as well as paclitaxel and pironetin, on the in vitro microtubule assembly. The lines in the figure show the turbidimetric time course of polymerization of tubulin in the presence of GTP, and in the presence of $27.5 \mu \mathrm{M}$ of each of the indicated compound.

Effect of pyranone derivatives on the hTERT, c-Myc and VEGF gene inhibition and on the VEGF protein secretion. We have also studied the ability of pyranones 1, 2, ent-1 and ent-2 to downregulate the expression of the hTERT and $c-M y c$ genes, both involved in telomerase activity, and the expression of the $V E G F$ gene and its associated protein VEGF, both involved in angiogenic activity. The expression of hTERT, $c-M y c$ and $V E G F$ genes were measured upon reverse transcription quantitative PCR (RT-qPCR) analysis on HT-29 tumoral cells. The VEGF protein production was determined with the ELISA procedure and corresponds mainly to the lighter VEGFA-165 isoform that is secreted to the culture medium. Table 2 shows expression percentage of the hTERT, $c-M y c$ and VEGF genes after $48 \mathrm{~h}$ of incubation of HT-29 cells. Table 2 also shows VEGF protein secretion percentage from HT-29 cells determined after $72 \mathrm{~h}$ of incubation of HT-29 cells.

Table 2. Percentages of gene expression and VEGF protein secretion

\begin{tabular}{cccccc} 
Comp. & Concent. & $\begin{array}{c}\boldsymbol{h T E R T}^{\mathbf{a}} \\
(\mathbf{\%})\end{array}$ & $\boldsymbol{c}-\boldsymbol{M y}^{\mathbf{a}} \mathbf{( \% )}$ & $\begin{array}{c}\boldsymbol{V E G F}^{\mathbf{a}} \\
(\mathbf{\%})\end{array}$ & $\begin{array}{c}\text { VEGF protein }^{\mathbf{a}} \\
(\%)\end{array}$ \\
\hline $\mathbf{1}$ & $5 \mu \mathrm{M}$ & $49 \pm 4$ & $18 \pm 1$ & $45 \pm 5$ & $29 \pm 4$ \\
$\mathbf{2}$ & $25 \mu \mathrm{M}$ & $42 \pm 7$ & $25 \pm 2$ & $26 \pm 1$ & $36 \pm 2$ \\
ent-1 & $25 \mu \mathrm{M}$ & $59 \pm 8$ & $36.5 \pm 1.5$ & $36 \pm 2$ & $63 \pm 7$ \\
ent-2 & $5 \mu \mathrm{M}$ & $39 \pm 5$ & $25 \pm 4$ & $19.0 \pm 0.2$ & $76 \pm 4$ \\
\hline
\end{tabular}

${ }^{\mathrm{a}}$ At least three measurements were performed in each case.

As regards the inhibition of the $h T E R T$ and $c-M y c$ genes, compounds $\mathbf{1}$ and ent-2 are the most active ones, especially if one considers that the concentration of these two compounds is five times lower than that of compounds $\mathbf{2}$ and ent-1. Particularly appealing is the activity of compound $\mathbf{1}$ on the inhibition in the expression of the $c-M y c$ gene, which is decreased to $18 \%$ of the control value. Regarding the $V E G F$ gene expression compound ent-2 shows the greatest inhibition. However, this high decrease in gene expression is not accompanied by a similar decrease in VEGF protein secretion as compound ent-2 downregulates protein secretion by only $24 \%$. In this sense, the most active compound is pyranone 1 which downregulates VEGF protein secretion by $71 \%$.

\section{Summary}

Pironetin analogues 1-4 and their enantiomers were synthesized with the aim at exploring the influence of the alkyl pendants as well as their stereochemistry and lactone ring size in their biological activity. Pyranones showed to be cytotoxic at micromolar level while furanones showed no cytotoxicity. Among pyranones the most cytotoxic were $\mathbf{1}$ and ent-2, which have the same configuration at the lactone stereocenter as pironetin. The influence of pyranones in tubulin polymerization was also measured but, in contrast to pironetin, they seem to have little influence in the tubulin polymerization process. It thus seems that removal of the methyl pendants at the side chain by a gem-dimethylated pattern causes a strong decrease in the interaction of the compounds with tubulin. As regards the inhibition of the $c-M y c$ and $V E G F$ genes, pyranones $\mathbf{1}$ and ent-2 proved to be the most active compounds with 1 showing the strongest inhibition of VEGF protein secretion.

\section{Experimental}

\section{Chemical procedures}

NMR spectra were recorded at $500 \mathrm{MHz}\left({ }^{1} \mathrm{H}\right.$ NMR) and 125 $\mathrm{MHz}\left({ }^{13} \mathrm{C} \mathrm{NMR}\right)$ in $\mathrm{CDCl}_{3}$ solution at $25{ }^{\circ} \mathrm{C}$, with the solvent signals as internal reference. ${ }^{13} \mathrm{C}$ NMR signal multiplicities were determined with the APT pulse sequence. Mass spectra were run in the electrospray (ESMS) mode. IR data, which were measured as films on $\mathrm{NaCl}$ plates (oils) or as $\mathrm{KBr}$ pellets (solids), are given only when relevant functions $(\mathrm{C}=\mathrm{O}, \mathrm{OH})$ are present. Optical rotations were measured at $25{ }^{\circ} \mathrm{C}$. Reactions which required an inert atmosphere were carried out under dry $\mathrm{N}_{2}$ with flame-dried glassware. Commercial reagents were used as received. THF and $\mathrm{Et}_{2} \mathrm{O}$ were freshly distilled from sodium-benzophenone ketyl. Dichloromethane was freshly distilled from $\mathrm{CaH}_{2}$. Toluene was freshly distilled from sodium wire. Tertiary amines were freshly distilled from $\mathrm{KOH}$.

$(3 R, 4 R, 5 R)-2,4,6,6-T e t r a m e t h y l o c t-7-e n e-3,5-d i o l \quad(5) . \quad T h e$ following reaction conditions should be strictly adhered to, with particular attention to the words highlighted in italics: D-proline (230 mg, $2 \mathrm{mmol}$ ) was dissolved under $\mathrm{N}_{2}$ in dry DMF $(2 \mathrm{~mL}$ ) and placed in an ice bath. After stirring for 5 minutes, freshly distilled isobutyraldehyde $(1.82 \mathrm{~mL}, 20 \mathrm{mmol})$ was added 
followed by dry DMF $(2.5 \mathrm{~mL})$. In a separate flask, freshly distilled propionaldehyde $(722 \mu \mathrm{L}, 10 \mathrm{mmol})$ was dissolved in dry DMF $(7 \mathrm{~mL})$. The resulting solution was ice-cooled and added dropwise to the isobutyraldehyde solution by means of syringe pump at a rate of $0.10 \mathrm{~mL} / \mathrm{h}$ (the needle of the pump should be just below the surface of the liquid). Caution: higher addition rates give rise to diminished yields! When all the propionaldehyde solution had been added, the reaction mixture was stirred at the same temperature for $15 \mathrm{~h}$. Subsequently, prenyl bromide $(2.31 \mathrm{~mL}, 20 \mathrm{mmol})$ was added dropwise (ca. 10 min.) followed by sodium iodide $(1.65 \mathrm{~g}, 11 \mathrm{mmol})$ and powdered metallic indium $(1.27 \mathrm{~g}, 11 \mathrm{mmol})$. The mixture was then very vigorously stirred for $5 \mathrm{~min}$. at $0{ }^{\circ} \mathrm{C}$. After allowing the mixture to reach room temperature, water $(11 \mathrm{~mL})$ was added and the stirring was continued for $48 \mathrm{~h}$. The reaction mixture was then poured onto saturated ammonium chloride and carefully extracted with EtOAc (caution, emulsions may be formed!). The organic layers were then dried over anhydrous $\mathrm{MgSO}_{4}$, filtered and evaporated under reduced pressure. The resulting oil was carefully chromatographed on silica gel (hexane-EtOAc, from 95:5 to 80:20). This yielded diol $5(801 \mathrm{mg}, 40 \%$ based on propionaldehyde) as off-white crystals (from $\mathrm{Et}_{2} \mathrm{O}-\mathrm{CHCl}_{3}$ ): $\mathrm{mp}$ 76-77 ${ }^{\circ} \mathrm{C}$ (from $\mathrm{Et}_{2} \mathrm{O}-\mathrm{CH}_{2} \mathrm{Cl}_{2}$ ), $[\alpha]_{\mathrm{D}}+17.6\left(c 1 ; \mathrm{CHCl}_{3}\right.$ ). Spectral data were consistent with those published ${ }^{17}$ (see Electronic Supplementary Information).

The procedure described above represents the maximum scale at which we were able to obtain reasonable yields. Attempts at increasing the scale only led to a decrease in the yield.

The procedure was repeated under the same conditions with Lproline to yield ent-5: $[\alpha]_{\mathrm{D}}-18.1\left(\mathrm{c} 1 ; \mathrm{CHCl}_{3}\right)$. Physical and spectral data identical to those of $\mathbf{5}$.

The stereostructures of $\mathbf{5}$ and ent- $\mathbf{5}$ have been secured by means of an X-ray diffraction analysis. ${ }^{24}$

(4R,5R,6R)-4,6-Dimethoxy-3,3,5,7-tetramethyloct-1-ene (6). Sodium hydride $(60 \%$ slurry in mineral oil, amount equivalent to $16 \mathrm{mmol}$ ) was washed two times under $\mathrm{N}_{2}$ with dry hexane and once with dry THF. Then, THF $(50 \mathrm{~mL})$ was added and the suspension was cooled in an ice bath. Alcohol 5 $(801 \mathrm{mg}, 4 \mathrm{mmol})$ was then dissolved in dry THF $(10 \mathrm{~mL})$ and added dropwise to the sodium hydride suspension. The mixture was then allowed to reach room temperature. Subsequently, methyl iodide $(1.25 \mathrm{~mL}, 20 \mathrm{mmol})$ was added dropwise and the mixture was stirred for $24 \mathrm{~h}$ at room temperature. The reaction mixture was then poured onto saturated ammonium chloride and extracted several times with $\mathrm{Et}_{2} \mathrm{O}$. The organic layers were then dried over anhydrous $\mathrm{Na}_{2} \mathrm{SO}_{4}$, filtered and evaporated under reduced pressure. The resulting oil was carefully chromatographed on silica gel (hexane-EtOAc, 95:5). This yielded $6(822 \mathrm{mg}, 90 \%)$ : oil, $[\alpha]_{\mathrm{D}}+1.8\left(c 1 ; \mathrm{CHCl}_{3}\right)$; ${ }^{1} \mathrm{H}$ NMR $\delta 5.99(1 \mathrm{H}, \mathrm{dd}, J=17.5,11 \mathrm{~Hz}), 4.98(1 \mathrm{H}, \mathrm{dd}, J=17.5$, $1.5 \mathrm{~Hz}), 4.94(1 \mathrm{H}, \mathrm{dd}, J=11,1.5 \mathrm{~Hz}), 3.44(3 \mathrm{H}, \mathrm{s}), 3.38(3 \mathrm{H}, \mathrm{s})$, $3.06(1 \mathrm{H}, \mathrm{dd}, J=6,3.5 \mathrm{~Hz}), 2.88(1 \mathrm{H}, \mathrm{d}, J=5 \mathrm{~Hz}), 1.98(1 \mathrm{H}, \mathrm{m})$, $1.88(1 \mathrm{H}$, br m), $1.08(3 \mathrm{H}, \mathrm{s}), 1.07(3 \mathrm{H}, \mathrm{s}), 0.99(3 \mathrm{H}, \mathrm{d}, J=7.5$ $\mathrm{Hz}), 0.93(3 \mathrm{H}, \mathrm{d}, J=7 \mathrm{~Hz}), 0.90(3 \mathrm{H}, \mathrm{d}, J=7 \mathrm{~Hz}) ;{ }^{13} \mathrm{C}$ NMR $\delta$ $43.2(\mathrm{C}), 146.6,91.6,86.9,38.8,30.3(\mathrm{CH}), 110.8\left(\mathrm{CH}_{2}\right), 61.4$, 59.5, 25.7, 23.3, 22.0, 17.1, $16.4\left(\mathrm{CH}_{3}\right)$; HR ESMS $\mathrm{m} / \mathrm{z} 251.1991$ $\left(\mathrm{M}+\mathrm{Na}^{+}\right)$, calcd. for $\mathrm{C}_{14} \mathrm{H}_{28} \mathrm{NaO}_{2}, 251.1987$. (ent-6): oil, $[\alpha]_{\mathrm{D}}-1.8\left(\right.$ c $\left.1 ; \mathrm{CHCl}_{3}\right)$. Physical and spectral data identical to those of 6 .

(4S,6R,7R,8R)-6,8-Dimethoxy-5,5,7,9-tetramethyldec-1-en4-ol (7) and $(4 R, 6 R, 7 R, 8 R)-6,8$-dimethoxy-5,5,7,9-tetramethyldec-1-en-4-ol (8). Olefin $6(685 \mathrm{mg}, 3 \mathrm{mmol})$ was dissolved in dry $\mathrm{CH}_{2} \mathrm{Cl}_{2}(60 \mathrm{~mL})$ and cooled to $-78^{\circ} \mathrm{C}$. A stream of ozone-oxygen was bubbled through the solution until persistence of the bluish color. Dry $\mathrm{N}_{2}$ was then bubbled through the solution for $10 \mathrm{~min}$. at the same temperature. After addition of $\mathrm{PPh}_{3}(1.18 \mathrm{~g}, 4.5 \mathrm{mmol})$, the solution was left to stir at room temperature for $2 \mathrm{~h}$. Solvent removal under reduced pressure gave a solid material, which was put on the top of a short silica gel pad and rapidly washed with hexaneEtOAc 9:1. After removal of volatiles under reduced pressure, the crude oily aldehyde was then directly used as such in the next allylation step (for weight calculations, the yield of the ozonolysis step was assumed to be quantitative).

The oily material from above was dissolved under $\mathrm{N}_{2}$ in dry THF $(15 \mathrm{~mL})$ and cooled in an ice bath. After this, a $1 \mathrm{M}$ solution of allylmagnesium bromide in THF ( $4 \mathrm{~mL}, 4 \mathrm{mmol})$ was added dropwise, and the mixture was allowed to reach room temperature, followed by stirring for $3 \mathrm{~h}$ (TLC monitoring). The reaction mixture was then poured onto saturated ammonium chloride and extracted several times with $\mathrm{Et}_{2} \mathrm{O}$. The organic layers were then dried over anhydrous $\mathrm{Na}_{2} \mathrm{SO}_{4}$, filtered and evaporated under reduced pressure. The resulting oil was the subjected to a slow and careful chromatography on silica gel (hexane-Et $\left.{ }_{2} \mathrm{O}, 9: 1\right)$ to yield $7(367 \mathrm{mg}, 45 \%)$ and $8(182 \mathrm{~g}$, $22 \%)$

(7): oil, $[\alpha]_{\mathrm{D}}-23.3\left(\mathrm{c} 1 ; \mathrm{CHCl}_{3}\right) ; \mathrm{IR} v_{\max }\left(\mathrm{cm}^{-1}\right): 3400$ (br, OH); ${ }^{1} \mathrm{H}$ NMR $\delta 5.90(1 \mathrm{H}$, ddt, $J=17,10.5,7 \mathrm{~Hz}), 5.01(1 \mathrm{H}, \mathrm{dm}, J \sim$ $17 \mathrm{~Hz}), 4.94(1 \mathrm{H}, \mathrm{dm}, J \sim 10.5 \mathrm{~Hz}), 4.90(1 \mathrm{H}$, br d, $J \sim 3 \mathrm{~Hz}$, $\mathrm{OH}), 3.68(1 \mathrm{H}, \mathrm{dt}, J=10,3 \mathrm{~Hz}), 3.45(6 \mathrm{H}, \mathrm{s}), 3.02(1 \mathrm{H}, \mathrm{dd}, J=$ 10, $1 \mathrm{~Hz}), 2.74(1 \mathrm{H}, \mathrm{d}, J=2.5 \mathrm{~Hz}), 2.38(1 \mathrm{H}, \mathrm{m}), 2.14(1 \mathrm{H}, \mathrm{m})$, $2.04(1 \mathrm{H}, \mathrm{m}), 1.81(1 \mathrm{H}, \mathrm{m}), 0.99(3 \mathrm{H}, \mathrm{d}, J=7 \mathrm{~Hz}), 0.90(3 \mathrm{H}, \mathrm{d}, J$ $=7.5 \mathrm{~Hz}), 0.89(3 \mathrm{H}, \mathrm{s}), 0.87(3 \mathrm{H}, \mathrm{s}), 0.80(3 \mathrm{H}, \mathrm{d}, J=7 \mathrm{~Hz}) ;{ }^{13} \mathrm{C}$ NMR $\delta 43.4(\mathrm{C}), 137.9,97.1,87.3,73.0,36.2,30.3(\mathrm{CH}), 115.1$, $35.9\left(\mathrm{CH}_{2}\right), 62.0,60.3,25.5,22.2,21.1,17.2,14.5\left(\mathrm{CH}_{3}\right)$; HR ESMS $m / z 273.2429\left(\mathrm{M}+\mathrm{H}^{+}\right)$, calcd. for $\mathrm{C}_{16} \mathrm{H}_{33} \mathrm{O}_{3}, 273.2430$.

(ent-7): oil, $[\alpha]_{\mathrm{D}}+21.5\left(c 1 ; \mathrm{CHCl}_{3}\right)$. Physical and spectral data identical to those of 7 .

(8): oil, $[\alpha]_{\mathrm{D}}+9.5\left(\mathrm{c} 1 ; \mathrm{CHCl}_{3}\right) ; \mathrm{IR} v_{\max }\left(\mathrm{cm}^{-1}\right): 3480(\mathrm{br}, \mathrm{OH}) ;{ }^{1} \mathrm{H}$ NMR $\delta 5.94(1 \mathrm{H}, \mathrm{ddt}, J=17,10.5,7 \mathrm{~Hz}), 5.08(1 \mathrm{H}, \mathrm{dm}, J \sim 17$ $\mathrm{Hz}), 5.04$ (1H, dm, $J \sim 10.5 \mathrm{~Hz}), 3.70(2 \mathrm{H}, \mathrm{m}), 3.47(3 \mathrm{H}, \mathrm{s}), 3.41$ $(3 \mathrm{H}, \mathrm{s}), 3.02(2 \mathrm{H}, \mathrm{m}), 2.22(1 \mathrm{H}, \mathrm{m}), 2.10(2 \mathrm{H}, \mathrm{m}), 1.90(1 \mathrm{H}, \mathrm{m})$, $1.03(3 \mathrm{H}, \mathrm{d}, J=7.5 \mathrm{~Hz}), 0.99(3 \mathrm{H}, \mathrm{s}), 0.98(3 \mathrm{H}, \mathrm{d}, J=7 \mathrm{~Hz}), 0.90$ $(3 \mathrm{H}, \mathrm{d}, J=7 \mathrm{~Hz}), 0.88(3 \mathrm{H}, \mathrm{s}) ;{ }^{13} \mathrm{C}$ NMR $\delta 42.9(\mathrm{C}), 137.4,95.1$, 86.8, 75.7, 37.0, $30.5(\mathrm{CH}), 115.9,36.7\left(\mathrm{CH}_{2}\right), 61.9,59.9,22.5$, 21.7, 21.0, 19.7, $16.0\left(\mathrm{CH}_{3}\right)$; HR ESMS $m / z 273.2430\left(\mathrm{M}+\mathrm{H}^{+}\right)$, calcd. for $\mathrm{C}_{16} \mathrm{H}_{33} \mathrm{O}_{3}, 273.2430$.

(ent-8): oil, $[\alpha]_{\mathrm{D}}-11.8\left(\right.$ ( $\left.1 ; \mathrm{CHCl}_{3}\right)$. Physical and spectral data identical to those of $\mathbf{8}$.

$(4 S, 6 R, 7 R, 8 R)-6,8$-Dimethoxy-5,5,7,9-tetramethyldec-1-en4-yl acrylate $(9)$ and $(4 R, 6 R, 7 R, 8 R)-6,8$-dimethoxy-5,5,7,9tetramethyldec-1-en-4-yl acrylate (10). Alcohol 7 or $8(82$ $\mathrm{mg}, 0.3 \mathrm{mmol})$ was dissolved under $\mathrm{N}_{2}$ in dry $\mathrm{CH}_{2} \mathrm{Cl}_{2}(5 \mathrm{~mL})$, 
cooled to $-78^{\circ} \mathrm{C}$ and treated sequentially with ethyl $N, N$ diisopropylamine $(160 \mu \mathrm{L}, 0.9 \mathrm{mmol})$ and acryloyl chloride $(50 \mu \mathrm{L}, 0.6 \mathrm{mmol})$. The reaction mixture was then stirred for 3 $\mathrm{h}$ at $-78^{\circ} \mathrm{C}$. The reaction mixture was then poured onto saturated ammonium chloride and extracted several times with $\mathrm{CH}_{2} \mathrm{Cl}_{2}$. The organic layers were then dried over anhydrous $\mathrm{MgSO}_{4}$, filtered and evaporated under reduced pressure. The resulting oil was the subjected in each case to chromatography on silica gel (hexane-EtOAc, 98:2) to afford $\mathbf{9}(81 \mathrm{mg}, 83 \%)$ and $\mathbf{1 0}(80 \mathrm{mg}$, $82 \%)$, respectively.

(9): oil, $[\alpha]_{\mathrm{D}}+6.8\left(\mathrm{c} 1 ; \mathrm{CHCl}_{3}\right)$; IR $v_{\max }\left(\mathrm{cm}^{-1}\right): 1724(\mathrm{C}=\mathrm{O}) ;{ }^{1} \mathrm{H}$ NMR $\delta 6.38(1 \mathrm{H}, \mathrm{dd}, J=17.5,1.5 \mathrm{~Hz}), 6.10(1 \mathrm{H}, \mathrm{dd}, J=17.5$, $10.5 \mathrm{~Hz}), 5.79(1 \mathrm{H}, \mathrm{dd}, J=10.5,1.5 \mathrm{~Hz}), 5.75(1 \mathrm{H}, \mathrm{m}), 5.20(1 \mathrm{H}$, dd, $J=10,2.5 \mathrm{~Hz}), 5.02(1 \mathrm{H}$, br dd, $J=17,1.5 \mathrm{~Hz}), 4.97(1 \mathrm{H}, \mathrm{br}$ dd, $J \sim 10,1.5 \mathrm{~Hz}), 3.43(3 \mathrm{H}, \mathrm{s}), 3.39(3 \mathrm{H}, \mathrm{s}), 3.05-3.00(2 \mathrm{H}, \mathrm{m})$, $2.59(1 \mathrm{H}, \mathrm{m}), 2.24(1 \mathrm{H}, \mathrm{m}), 2.04(1 \mathrm{H}, \mathrm{d}$ quint, $J=7,4 \mathrm{~Hz}), 1.90$ $(1 \mathrm{H}, \mathrm{d}$ quint, $J=7,2.5 \mathrm{~Hz}), 1.02(3 \mathrm{H}, \mathrm{d}, J=7.5 \mathrm{~Hz}), 0.98(3 \mathrm{H}, \mathrm{d}$, $J=7.5 \mathrm{~Hz}), 0.96(3 \mathrm{H}, \mathrm{s}), 0.95(3 \mathrm{H}, \mathrm{s}), 0.90(3 \mathrm{H}, \mathrm{d}, J=7 \mathrm{~Hz}) ;{ }^{13} \mathrm{C}$ NMR $\delta 165.8,43.6(\mathrm{C}), 135.6,128.9,90.2,86.4,77.7,37.5,30.5$ (CH), 130.1, 116.7, $35.5\left(\mathrm{CH}_{2}\right), 60.9,59.7,21.7,20.8,20.3,18.8$, $16.1\left(\mathrm{CH}_{3}\right)$; HR ESMS $\mathrm{m} / \mathrm{z} 349.2359\left(\mathrm{M}+\mathrm{Na}^{+}\right)$, calcd. for $\mathrm{C}_{19} \mathrm{H}_{34} \mathrm{NaO}_{4}, 349.2355$.

(ent-9): oil, $[\alpha]_{\mathrm{D}}-9.1\left(\right.$ c $\left.1 ; \mathrm{CHCl}_{3}\right)$. Physical and spectral data identical to those of 9 .

(10): oil, $[\alpha]_{\mathrm{D}}-22.8$ (c 1; $\left.\mathrm{CHCl}_{3}\right)$; IR $v_{\max }\left(\mathrm{cm}^{-1}\right)$ : $1726(\mathrm{C}=\mathrm{O})$; ${ }^{1} \mathrm{H}$ NMR $\delta 6.38(1 \mathrm{H}, \mathrm{dd}, J=17.5,1.5 \mathrm{~Hz}), 6.11(1 \mathrm{H}, \mathrm{dd}, J=17.5$, $10.5 \mathrm{~Hz}), 5.80(1 \mathrm{H}, \mathrm{dd}, J=10.5,1.5 \mathrm{~Hz}), 5.76(1 \mathrm{H}, \mathrm{m}), 5.23(1 \mathrm{H}$, dd, $J=10,3 \mathrm{~Hz}), 5.01(1 \mathrm{H}$, br dd, $J=17,1.5 \mathrm{~Hz}), 4.97(1 \mathrm{H}, \mathrm{br}$ $\mathrm{dd}, J \sim 10,1.5 \mathrm{~Hz}), 3.39(3 \mathrm{H}, \mathrm{s}), 3.33(3 \mathrm{H}, \mathrm{s}), 3.02(1 \mathrm{H}, \mathrm{dd}, J=$ 8.5, $2 \mathrm{~Hz}), 2.94(1 \mathrm{H}, \mathrm{d}, J=3.5 \mathrm{~Hz}), 2.45(1 \mathrm{H}, \mathrm{m}), 2.24(1 \mathrm{H}, \mathrm{m})$, $1.98(1 \mathrm{H}, \mathrm{d}$ quint, $J=6.5,3.5 \mathrm{~Hz}), 1.89$ ( $1 \mathrm{H}, \mathrm{d}$ quint, $J=7,2.5$ $\mathrm{Hz}), 1.02(3 \mathrm{H}, \mathrm{d}, J=7 \mathrm{~Hz}), 0.97(3 \mathrm{H}, \mathrm{d}, J=7 \mathrm{~Hz}), 0.96(3 \mathrm{H}, \mathrm{s})$, $0.94(3 \mathrm{H}, \mathrm{s}), 0.88(3 \mathrm{H}, \mathrm{d}, J=6.5 \mathrm{~Hz}) ;{ }^{13} \mathrm{C} \mathrm{NMR} \delta 165.8,43.4$ (C), 135.5, 129.1, 88.3, 86.2, 76.8, 37.6, $30.5(\mathrm{CH}), 130.1,116.8$, $35.1\left(\mathrm{CH}_{2}\right), 60.7,59.8,21.7,19.1,19.0,18.5,15.6\left(\mathrm{CH}_{3}\right)$; HR ESMS $m / z 349.2360\left(\mathrm{M}+\mathrm{Na}^{+}\right)$, calcd. for $\mathrm{C}_{19} \mathrm{H}_{34} \mathrm{NaO}_{4}, 349.2355$.

(ent-10): oil, $[\alpha]_{\mathrm{D}}+17.8\left(\right.$ c $\left.1 ; \mathrm{CHCl}_{3}\right)$.

$(6 S)$-[ $(3 R, 4 R, 5 R)-3,5$-Dimethoxy-2,4,6-trimethylheptan-2yl]-5,6-dihydro-2H-pyran-2-one (1) and $(6 R)-[(3 R, 4 R, 5 R)-$ 3,5-dimethoxy-2,4,6-trimethylheptan-2-yl]-5,6-dihydro-

2H-pyran-2-one (2). Diolefin 9 or $\mathbf{1 0}(65 \mathrm{mg}, 0.2 \mathrm{mmol})$ was dissolved under $\mathrm{N}_{2}$ in dry, degassed $\mathrm{CH}_{2} \mathrm{Cl}_{2}(20 \mathrm{~mL})$ and treated with Grubbs first-generation ruthenium catalyst Ru-I $(16 \mathrm{mg}$, ca. $0.02 \mathrm{mmol})$. The mixture was heated at reflux until consumption of the starting material (2-3 h, TLC monitoring!). Removal of volatiles under reduced pressure and column chromatography of the residue on silica gel (hexane-EtOAc 9:1) furnished the desired metathesis products 1 (57 mg, 97\%) and 2 (56 mg, 96\%), respectively.

(1): oil, $[\alpha]_{\mathrm{D}}-78.2\left(\right.$ c 1.05; $\left.\mathrm{CHCl}_{3}\right)$; IR $v_{\max }\left(\mathrm{cm}^{-1}\right): 1725(\mathrm{C}=\mathrm{O})$; ${ }^{1} \mathrm{H}$ NMR $\delta 6.92(1 \mathrm{H}, \mathrm{ddd}, J=9.5,6.5,2.5 \mathrm{~Hz}), 6.00(1 \mathrm{H}, \mathrm{dd}, J=$ 9.5, $2 \mathrm{~Hz}), 4.38(1 \mathrm{H}, \mathrm{dd}, J=12.5,3.5 \mathrm{~Hz}), 3.42(3 \mathrm{H}, \mathrm{s}), 3.39(3 \mathrm{H}$, s), $3.20(1 \mathrm{H}, \mathrm{d}, J=3 \mathrm{~Hz}), 3.00(1 \mathrm{H}, \mathrm{dd}, J=8,3 \mathrm{~Hz}), 2.49(1 \mathrm{H}$, ddt, $J=18,12.5,2.5 \mathrm{~Hz}), 2.36(1 \mathrm{H}, \mathrm{ddd}, J=18,6.5,3.5 \mathrm{~Hz})$, 2.00-1.85 (2H, m), $1.02(3 \mathrm{H}, \mathrm{d}, J=7 \mathrm{~Hz}), 0.97(3 \mathrm{H}, \mathrm{d}, J=7 \mathrm{~Hz})$, $0.91(3 \mathrm{H}, \mathrm{s}), 0.86(3 \mathrm{H}, \mathrm{d}, J=7 \mathrm{~Hz}), 0.85(3 \mathrm{H}, \mathrm{s}) ;{ }^{13} \mathrm{C} \mathrm{NMR} \delta$ 164.9, 42.7 (C), 146.3, 121.1, 89.6, 86.3, 82.7, 37.3, $30.4(\mathrm{CH})$,
$25.4\left(\mathrm{CH}_{2}\right), 61.1,59.8,21.7,20.3,19.8,19.1,15.7\left(\mathrm{CH}_{3}\right) ; \mathrm{HR}$ ESMS $m / z 321.2040\left(\mathrm{M}+\mathrm{Na}^{+}\right)$, calcd. for $\mathrm{C}_{17} \mathrm{H}_{30} \mathrm{NaO}_{4}, 321.2042$.

(ent-1): oil, $[\alpha]_{\mathrm{D}}+71.4\left(\right.$ c $\left.1 ; \mathrm{CHCl}_{3}\right)$. Physical and spectral data identical to those of $\mathbf{1}$.

(2): off-white solid, mp 67-69 ${ }^{\circ} \mathrm{C}$ (from $\mathrm{Et}_{2} \mathrm{O}-\mathrm{CH}_{2} \mathrm{Cl}_{2}$ ), $[\alpha]_{\mathrm{D}}$ -10.6 (c 1; $\left.\mathrm{CHCl}_{3}\right)$; IR $v_{\max }\left(\mathrm{cm}^{-1}\right): 1727(\mathrm{C}=\mathrm{O}) ;{ }^{1} \mathrm{H}$ NMR $\delta 6.93$ (1H, ddd, $J=9.5,6.5,2 \mathrm{~Hz}), 6.00(1 \mathrm{H}, \mathrm{dd}, J=9.5,2 \mathrm{~Hz}), 4.58$ $(1 \mathrm{H}, \mathrm{dd}, J=13,3.5 \mathrm{~Hz}), 3.43(3 \mathrm{H}, \mathrm{s}), 3.37$ (4H overall, an OMe singlet overlapping an one-proton signal), $2.99(1 \mathrm{H}, \mathrm{dd}, J=8,2.5$ $\mathrm{Hz}), 2.37$ (1H, ddt, $J=18,13,2.5 \mathrm{~Hz}), 2.25(1 \mathrm{H}$, ddd, $J=18,6.5$, $3.5 \mathrm{~Hz}), 1.90-1.80(2 \mathrm{H}, \mathrm{m}), 1.02(3 \mathrm{H}, \mathrm{d}, J=7 \mathrm{~Hz}), 0.97(3 \mathrm{H}, \mathrm{d}, J$ $=7 \mathrm{~Hz}), 0.91(3 \mathrm{H}, \mathrm{s}), 0.86(3 \mathrm{H}, \mathrm{d}, J=7 \mathrm{~Hz}), 0.85(3 \mathrm{H}, \mathrm{s}) ;{ }^{13} \mathrm{C}$ NMR $\delta 164.8,42.5$ (C), 146.1, 121.1, 87.4, 86.2, 81.1, 37.2, 30.4 $(\mathrm{CH}), 24.4\left(\mathrm{CH}_{2}\right), 61.1,59.8,21.7,19.8,18.2,17.4,15.5\left(\mathrm{CH}_{3}\right)$; HR ESMS $m / z 321.2040\left(\mathrm{M}+\mathrm{Na}^{+}\right)$, calcd. for $\mathrm{C}_{17} \mathrm{H}_{30} \mathrm{NaO}_{4}$, 321.2042 .

(ent-2): off-white solid, $[\alpha]_{\mathrm{D}}+6.1\left(\mathrm{c} 1 ; \mathrm{CHCl}_{3}\right)$. Physical and spectral data identical to those of 2 .

The stereostructures of $\mathbf{2}$ and ent-2 have been secured by means of an X-ray diffraction analysis. ${ }^{24}$

$(3 S, 5 R, 6 R, 7 R)-5,7-D i m e t h o x y-4,4,6,8$-tetramethylnon-1-en3-ol (11) and $(3 R, 5 R, 6 R, 7 R)-5,7-d i m e t h o x y-4,4,6,8$-tetramethylnon-1-en-3-ol (12). Olefin $6(685 \mathrm{mg}, 3 \mathrm{mmol})$ was dissolved in dry $\mathrm{CH}_{2} \mathrm{Cl}_{2}(60 \mathrm{~mL})$ and cooled to $-78^{\circ} \mathrm{C}$. A stream of ozone-oxygen was bubbled through the solution until persistence of the bluish color. Dry $\mathrm{N}_{2}$ was then bubbled through the solution for $10 \mathrm{~min}$. at the same temperature. After addition of $\mathrm{PPh}_{3}(1.18 \mathrm{~g}, 4.5 \mathrm{mmol})$, the solution was left to stir at room temperature for $2 \mathrm{~h}$. Solvent removal under reduced pressure gave a solid material, which was put on the top of a short silica gel pad and rapidly washed with hexaneEtOAc 9:1. After removal of volatiles under reduced pressure, the crude oily aldehyde was then directly used as such in the next allylation step (for weight calculations, the yield of the ozonolysis step was assumed to be quantitative).

The oily material from above was dissolved under $\mathrm{N}_{2}$ in dry THF $(15 \mathrm{~mL})$ and cooled in an ice bath. After this, a $1.6 \mathrm{M}$ solution of vinylmagnesium chloride in THF $(2.5 \mathrm{~mL}, 4$ mmol) was added dropwise, and the mixture was allowed to reach room temperature, followed by stirring for $2 \mathrm{~h}$ (TLC monitoring). The reaction mixture was then poured onto saturated ammonium chloride and extracted several times with $\mathrm{Et}_{2} \mathrm{O}$. The organic layers were then dried over anhydrous $\mathrm{Na}_{2} \mathrm{SO}_{4}$, filtered and evaporated under reduced pressure. The resulting oil was the subjected to a slow and careful chromatography on silica gel (hexane- $\mathrm{Et}_{2} \mathrm{O}$, from 98:2 to 95:5) to yield $\mathbf{1 1}$ (255 mg, 33\%) and 12 (240 $\mathrm{mg}, 31 \%)$.

(11): oil, $[\alpha]_{\mathrm{D}}-26.4\left(\mathrm{c} 1 ; \mathrm{CHCl}_{3}\right)$; IR $v_{\max }\left(\mathrm{cm}^{-1}\right): 3380(\mathrm{br}, \mathrm{OH})$; ${ }^{1} \mathrm{H}$ NMR $\delta 5.85(1 \mathrm{H}$, ddd, $J=17,10.5,6.5 \mathrm{~Hz}), 5.22(1 \mathrm{H}, \mathrm{br} \mathrm{d}, J$ $\sim 17 \mathrm{~Hz}), 5.20(1 \mathrm{H}$, br s, OH), $5.09(1 \mathrm{H}$, br d, $J \sim 10.5 \mathrm{~Hz}), 4.17$ $(1 \mathrm{H}, \mathrm{m}), 3.47(6 \mathrm{H}, \mathrm{s}), 3.05(1 \mathrm{H}, \mathrm{dd}, J=10,1.5 \mathrm{~Hz}), 2.80(1 \mathrm{H}, \mathrm{br}$ d, $J \sim 3 \mathrm{~Hz}), 2.38(1 \mathrm{H}, \mathrm{m}), 1.83(1 \mathrm{H}, \mathrm{m}), 1.00(3 \mathrm{H}, \mathrm{s}), 0.91(3 \mathrm{H}$, d, $J=7.5 \mathrm{~Hz}), 0.88(3 \mathrm{H}, \mathrm{s}), 0.85(3 \mathrm{H}, \mathrm{s}), 0.81(3 \mathrm{H}, \mathrm{d}, J=7 \mathrm{~Hz})$; ${ }^{13} \mathrm{C}$ NMR $\delta 43.1(\mathrm{C}), 138.0,96.5,87.2,75.1,36.2,30.3(\mathrm{CH})$, $115.3\left(\mathrm{CH}_{2}\right), 61.9,60.3,25.6,22.0,21.1,17.1,14.5\left(\mathrm{CH}_{3}\right)$; HR ESMS $m / z 281.2094\left(\mathrm{M}+\mathrm{Na}^{+}\right)$, calcd. for $\mathrm{C}_{15} \mathrm{H}_{30} \mathrm{NaO}_{3}, 281.2093$. 
(ent-11): oil, $[\alpha]_{\mathrm{D}}+22.4\left(\right.$ c $\left.1 ; \mathrm{CHCl}_{3}\right)$. Physical and spectral data identical to those of $\mathbf{1 1}$.

(12): oil, $[\alpha]_{\mathrm{D}}+17.9$ (c 1; $\left.\mathrm{CHCl}_{3}\right)$; IR $v_{\max }\left(\mathrm{cm}^{-1}\right): 3450$ (br, OH); ${ }^{1} \mathrm{H}$ NMR $\delta 5.90(1 \mathrm{H}, \mathrm{ddd}, J=17,10.5,6 \mathrm{~Hz}), 5.27(1 \mathrm{H}, \mathrm{br} \mathrm{d}, J \sim$ $17 \mathrm{~Hz}), 5.15(1 \mathrm{H}$, br d, $J \sim 10.5 \mathrm{~Hz}), 4.11(1 \mathrm{H}, \mathrm{m}), 3.95(1 \mathrm{H}, \mathrm{br}$ d, $J \sim 4 \mathrm{~Hz}, \mathrm{OH}), 3.45(3 \mathrm{H}, \mathrm{s}), 3.41(3 \mathrm{H}, \mathrm{s}), 3.08(1 \mathrm{H}, \mathrm{d}, J=4$ $\mathrm{Hz}), 3.01(1 \mathrm{H}, \mathrm{d}, J=8.5,2 \mathrm{~Hz}), 2.06(1 \mathrm{H}, \mathrm{m}), 1.89(1 \mathrm{H}, \mathrm{m}), 1.03$ $(3 \mathrm{H}, \mathrm{d}, J=7 \mathrm{~Hz}), 0.98(3 \mathrm{H}, \mathrm{d}, J=7 \mathrm{~Hz}), 0.96(3 \mathrm{H}, \mathrm{s}), 0.89(3 \mathrm{H}$, s), $0.88(3 \mathrm{H}, \mathrm{d}, J=7 \mathrm{~Hz}) ;{ }^{13} \mathrm{C} \mathrm{NMR} \delta 42.6(\mathrm{C}), 138.0,94.4,86.7$, 78.4, 37.1, $30.4(\mathrm{CH}), 115.9\left(\mathrm{CH}_{2}\right), 61.4,60.0,22.3,21.6,21.2$, 19.6, $15.6\left(\mathrm{CH}_{3}\right)$; HR ESMS $m / z 281.2095\left(\mathrm{M}+\mathrm{Na}^{+}\right)$, calcd. for $\mathrm{C}_{15} \mathrm{H}_{30} \mathrm{NaO}_{3}, 281.2093$.

(ent-12): oil, $[\alpha]_{\mathrm{D}}-16.9$ ( c 1; $\mathrm{CHCl}_{3}$ ). Physical and spectral data identical to those of $\mathbf{1 2}$.

(3S,5R,6R,7R)-5,7-Dimethoxy-4,4,6,8-tetramethylnon-1-en3 -yl acrylate $(13)$ and $(3 R, 5 R, 6 R, 7 R)$-5,7-dimethoxy-4,4,6,8tetramethylnon-1-en-3-yl acrylate (14). Alcohol 11 or 12 were subjected to esterification with acryloyl chloride under the same conditions used for the preparation of 9 and 10. In this way, acrylates $13(85 \%)$ and $\mathbf{1 4}(84 \%)$ were obtained.

(13): oil, $[\alpha]_{\mathrm{D}}-20.7\left(c 1 ; \mathrm{CHCl}_{3}\right)$; IR $v_{\max }\left(\mathrm{cm}^{-1}\right)$ : $1728(\mathrm{C}=\mathrm{O})$; ${ }^{1} \mathrm{H}$ NMR $\delta 6.42(1 \mathrm{H}, \mathrm{dd}, J=17.5,1.5 \mathrm{~Hz}), 6.15(1 \mathrm{H}, \mathrm{dd}, J=17.5$, $10.5 \mathrm{~Hz}), 5.90(1 \mathrm{H}, \mathrm{ddd}, J=17.5,10.5,7 \mathrm{~Hz}), 5.83(1 \mathrm{H}, \mathrm{dd}, J=$ 10.5, $1.5 \mathrm{~Hz}), 5.37(1 \mathrm{H}$, br d, $J \sim 7 \mathrm{~Hz}), 5.30-5.20(2 \mathrm{H}, \mathrm{m}), 3.41$ $(3 \mathrm{H}, \mathrm{s}), 3.40(3 \mathrm{H}, \mathrm{s}), 3.07(1 \mathrm{H}, \mathrm{d}, J=3.5 \mathrm{~Hz}), 3.03(1 \mathrm{H}, \mathrm{dd}, J=8$, $2 \mathrm{~Hz}), 2.00(1 \mathrm{H}$, d quint, $J=7,3.5 \mathrm{~Hz}), 1.88(1 \mathrm{H}, \mathrm{d}$ quint, $J=7$, $2.5 \mathrm{~Hz}), 1.03(3 \mathrm{H}, \mathrm{d}, J=8 \mathrm{~Hz}), 1.02(3 \mathrm{H}, \mathrm{s}), 0.95(3 \mathrm{H}, \mathrm{d}, J=8$ $\mathrm{Hz}), 0.94(3 \mathrm{H}, \mathrm{s}), 0.88(3 \mathrm{H}, \mathrm{d}, J=6.5 \mathrm{~Hz}) ;{ }^{13} \mathrm{C} \mathrm{NMR} \delta 165.3$, $43.5(\mathrm{C}), 133.8,128.9,88.9,86.2,79.7,37.5,30.5(\mathrm{CH}), 130.4$, $118.2\left(\mathrm{CH}_{2}\right), 60.4,59.8,21.7,19.8$ (x 2), 18.6, $15.7\left(\mathrm{CH}_{3}\right)$; HR ESMS $m / z 335.2201\left(\mathrm{M}+\mathrm{Na}^{+}\right)$, calcd. for $\mathrm{C}_{18} \mathrm{H}_{32} \mathrm{NaO}_{4}, 335.2198$.

(ent-13): oil, $[\alpha]_{\mathrm{D}}+20.8\left(\right.$ ( $\left.1 ; \mathrm{CHCl}_{3}\right)$. Physical and spectral data identical to those of $\mathbf{1 3}$.

(14): oil, $[\alpha]_{\mathrm{D}}+16.7$ (c 1; $\left.\mathrm{CHCl}_{3}\right)$; IR $v_{\max }\left(\mathrm{cm}^{-1}\right)$ : $1729(\mathrm{C}=\mathrm{O})$; ${ }^{1} \mathrm{H}$ NMR $\delta 6.42(1 \mathrm{H}, \mathrm{dd}, J=17.5,1.5 \mathrm{~Hz}), 6.16(1 \mathrm{H}, \mathrm{dd}, J=17.5$, $10.5 \mathrm{~Hz}), 5.90-5.80(2 \mathrm{H}, \mathrm{m}), 5.42(1 \mathrm{H}$, br d, $J \sim 7 \mathrm{~Hz}), 5.30-5.20$ $(2 \mathrm{H}, \mathrm{m}), 3.41(3 \mathrm{H}, \mathrm{s}), 3.31(3 \mathrm{H}, \mathrm{s}), 3.06(1 \mathrm{H}, \mathrm{d}, J=3 \mathrm{~Hz}), 3.03$ $(1 \mathrm{H}, \mathrm{dd}, J=8,2 \mathrm{~Hz}), 1.93(1 \mathrm{H}, \mathrm{d}$ quint, $J=7,3.5 \mathrm{~Hz}), 1.85(1 \mathrm{H}$, d quint, $J=7,2.5 \mathrm{~Hz}), 1.00(3 \mathrm{H}, \mathrm{d}, J=7 \mathrm{~Hz}), 0.94(3 \mathrm{H}, \mathrm{d}, J=7.5$ $\mathrm{Hz}), 0.91(3 \mathrm{H}, \mathrm{s}), 0.89$ (3H, s), $0.84(3 \mathrm{H}, \mathrm{d}, J=7 \mathrm{~Hz}) ;{ }^{13} \mathrm{C}$ NMR $\delta 165.2,42.8(\mathrm{C}), 133.4,128.9,87.7,86.2,78.6,37.5,30.4(\mathrm{CH})$, 130.3, $118.3\left(\mathrm{CH}_{2}\right), 60.5,59.8,21.6,18.7,18.6$ (x 2), $15.5\left(\mathrm{CH}_{3}\right)$; HR ESMS $m / z 335.2198\left(\mathrm{M}+\mathrm{Na}^{+}\right)$, calcd. for $\mathrm{C}_{18} \mathrm{H}_{32} \mathrm{NaO}_{4}$, 335.2198

(ent-14): oil, $[\alpha]_{\mathrm{D}}-17.2\left(\right.$ c $\left.1 ; \mathrm{CHCl}_{3}\right)$. Physical and spectral data identical to those of $\mathbf{1 4}$.

$(5 S)-[(3 R, 4 R, 5 R)-3,5-D i m e t h o x y-2,4,6-t r i m e t h y l h e p t a n-2-$ yl]furan-2(5H)-one (3) and $(5 R)-[(3 R, 4 R, 5 R)-3,5-$ dimethoxy-2,4,6-trimethylheptan-2-yl]furan-2(5H)-one (4). Diolefin 13 or $14(62 \mathrm{mg}, 0.2 \mathrm{mmol})$ was dissolved under $\mathrm{N}_{2}$ in dry, degassed toluene $(20 \mathrm{~mL})$ and treated with Grubbs second-generation ruthenium catalyst Ru-II (17 mg, ca. 0.02 mmol). The mixture was then heated at $80^{\circ} \mathrm{C}$ for $36 \mathrm{~h}$. An addditional amount of ruthenium catalyst $(10 \mathrm{mg})$ was added and the heating was continued until consumption of the starting material (ca. 3 d overall, TLC monitoring!). Removal of volatiles under reduced pressure and column chromatography of the residue on silica gel (hexane-EtOAc 9:1) furnished the desired metathesis products 3 (48 $\mathrm{mg}, 85 \%)$ and $4(45 \mathrm{mg}, 79 \%)$, respectively.

(3): oil, $[\alpha]_{\mathrm{D}}-98.3\left(\mathrm{c} 1 ; \mathrm{CHCl}_{3}\right) ; \mathrm{IR} v_{\max }\left(\mathrm{cm}^{-1}\right): 1758(\mathrm{C}=\mathrm{O}) ;{ }^{1} \mathrm{H}$ NMR $\delta 7.61(1 \mathrm{H}, \mathrm{dd}, J=6,1.5 \mathrm{~Hz}), 6.01(1 \mathrm{H}, \mathrm{dd}, J=6,2 \mathrm{~Hz})$, $5.00(1 \mathrm{H}, \mathrm{dd}, J=2,1.5 \mathrm{~Hz}), 3.39(3 \mathrm{H}, \mathrm{s}), 3.31(3 \mathrm{H}, \mathrm{s}), 2.99(1 \mathrm{H}$, dd, $J=9.5,2.5 \mathrm{~Hz}), 2.94(1 \mathrm{H}, \mathrm{d}, J=3.5 \mathrm{~Hz}), 2.00(1 \mathrm{H}, \mathrm{m}), 1.89$ $(1 \mathrm{H}, \mathrm{m}), 1.07(3 \mathrm{H}, \mathrm{s}), 1.04(3 \mathrm{H}, \mathrm{d}, J=7.5 \mathrm{~Hz}), 0.99(3 \mathrm{H}, \mathrm{d}, J=$ $7.5 \mathrm{~Hz}), 0.94(3 \mathrm{H}, \mathrm{s}), 0.86(3 \mathrm{H}, \mathrm{d}, J=7 \mathrm{~Hz}) ;{ }^{13} \mathrm{C} \mathrm{NMR} \delta 173.6$, 44.3 (C), 157.3, 119.4, 89.6, 88.8, 86.1, 37.3, $30.4(\mathrm{CH}), 60.3$, $60.0,21.4,21.1,20.8,19.0,15.3\left(\mathrm{CH}_{3}\right)$; HR ESMS $m / z 307.1882$ $\left(\mathrm{M}+\mathrm{Na}^{+}\right)$, calcd. for $\mathrm{C}_{16} \mathrm{H}_{28} \mathrm{NaO}_{4}, 307.1885$.

(ent-3): off-white solid, $[\alpha]_{\mathrm{D}}+91\left(c \quad 1 ; \mathrm{CHCl}_{3}\right)$. Physical and spectral data identical to those of $\mathbf{3}$.

(4): off-white solid, mp 57-59 ${ }^{\circ} \mathrm{C}$ (from $\mathrm{Et}_{2} \mathrm{O}-\mathrm{CH}_{2} \mathrm{Cl}_{2}$ ), $[\alpha]_{\mathrm{D}}+47$ (c 1; $\left.\mathrm{CHCl}_{3}\right)$; IR $v_{\max }\left(\mathrm{cm}^{-1}\right): 1759(\mathrm{C}=\mathrm{O}) ;{ }^{1} \mathrm{H}$ NMR $\delta 7.50(1 \mathrm{H}$, $\mathrm{dd}, J=6,1.5 \mathrm{~Hz}), 6.10(1 \mathrm{H}, \mathrm{dd}, J=6,2 \mathrm{~Hz}), 5.17(1 \mathrm{H}, \mathrm{dd}, J=2$, $1.5 \mathrm{~Hz}), 3.47(3 \mathrm{H}, \mathrm{s}), 3.37(3 \mathrm{H}, \mathrm{s}), 3.22(1 \mathrm{H}, \mathrm{d}, J=4 \mathrm{~Hz}), 2.97$ $(1 \mathrm{H}, \mathrm{dd}, J=8,2.5 \mathrm{~Hz}), 1.90-1.80(2 \mathrm{H}, \mathrm{m}), 1.00(3 \mathrm{H}, \mathrm{d}, J=7 \mathrm{~Hz})$, $0.97(3 \mathrm{H}, \mathrm{s}), 0.93(3 \mathrm{H}, \mathrm{d}, J=7 \mathrm{~Hz}), 0.84(3 \mathrm{H}, \mathrm{d}, J=7 \mathrm{~Hz}), 0.69$ $(3 \mathrm{H}, \mathrm{s}) ;{ }^{13} \mathrm{C}$ NMR $\delta 173.2,43.5(\mathrm{C}), 155.8,122.2,88.9,87.8$, 86.1, 37.2, $30.4(\mathrm{CH}), 60.8,59.8,21.5,19.4,17.9,17.6,15.3$ $\left(\mathrm{CH}_{3}\right)$; HR ESMS $m / z 307.1888\left(\mathrm{M}+\mathrm{Na}^{+}\right)$, calcd. for $\mathrm{C}_{16} \mathrm{H}_{28} \mathrm{NaO}_{4}$, 307.1885 .

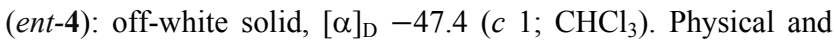
spectral data identical to those of 4 .

The stereostructures of $\mathbf{4}$ and ent- $\mathbf{4}$ have been secured by means of an X-ray diffraction analysis. ${ }^{24}$

$(5 R, 6 R, 7 R)$-5-Isopropyl-2,2,3,3,6,9,9,10,10-nonamethyl-7(2-methylbut-3-en-2-yl)-4,8-dioxa-3,9-disilaundecane (15). Alcohol 5 ( $800 \mathrm{mg}, 4 \mathrm{mmol})$ was dissolved under $\mathrm{N}_{2}$ in dry $\mathrm{CH}_{2} \mathrm{Cl}_{2}(25 \mathrm{~mL})$ and treated sequentially with 2,6-lutidine (1.4 $\mathrm{mL}, 12 \mathrm{mmol})$ and TBSOTf $(2.1 \mathrm{~mL}, 9 \mathrm{mmol})$. The reaction mixture was then stirred for $12 \mathrm{~h}$ at $30^{\circ} \mathrm{C}$. The reaction mixture was then poured onto saturated ammonium chloride and extracted several times with $\mathrm{CH}_{2} \mathrm{Cl}_{2}$. The organic layers were then dried over anhydrous $\mathrm{Mg}_{2} \mathrm{SO}_{4}$, filtered and evaporated under reduced pressure. The resulting oil was then subjected to column chromatography on silica gel (hexane) to yield 15 (1.55 g, 90\%): oil, $[\alpha]_{\mathrm{D}}+4.9\left(c 1 ; \mathrm{CHCl}_{3}\right) ;{ }^{1} \mathrm{H}$ NMR $\delta 6.20(1 \mathrm{H}, \mathrm{dd}, J=17.5,11$ $\mathrm{Hz}), 5.00(1 \mathrm{H}$, br d, $J \sim 17.5 \mathrm{~Hz}), 4.96(1 \mathrm{H}, \mathrm{dd}, J \sim 11 \mathrm{~Hz}), 3.90$ $(1 \mathrm{H}, \mathrm{d}, J=7.5 \mathrm{~Hz}), 3.75(1 \mathrm{H}, \mathrm{d}, J=1 \mathrm{~Hz}), 2.07$ (1H, br quint, $J \sim$ $7 \mathrm{~Hz}), 1.94(1 \mathrm{H}$, br quint, $J \sim 7 \mathrm{~Hz}), 1.12(3 \mathrm{H}, \mathrm{s}), 1.10(3 \mathrm{H}, \mathrm{s})$, 0.99 (3H, d overlapped), $0.98(9 \mathrm{H}, \mathrm{s}), 0.96(9 \mathrm{H}, \mathrm{s}), 0.91(3 \mathrm{H}, \mathrm{d}, J$ $=7 \mathrm{~Hz}), 0.88(3 \mathrm{H}, \mathrm{d}, J=7 \mathrm{~Hz}), 0.16(3 \mathrm{H}, \mathrm{s}), 0.12(3 \mathrm{H}, \mathrm{s}), 0.09$ $(3 \mathrm{H}, \mathrm{s}), 0.05(3 \mathrm{H}, \mathrm{s}) ;{ }^{13} \mathrm{C}$ NMR $\delta 42.8,18.6,18.5(\mathrm{C}), 146.5$, 80.7, 76.5, 45.2, $31.0(\mathrm{CH}), 110.0\left(\mathrm{CH}_{2}\right), 26.7,26.3(\mathrm{x} 3), 26.2(\mathrm{x}$ 3), 25.8, 21.0, 16.2, 13.5, -2.9, -3.0, -4.3, $-4.4\left(\mathrm{CH}_{3}\right)$; HR ESMS $m / z 451.3408\left(\mathrm{M}+\mathrm{Na}^{+}\right)$, calcd. for $\mathrm{C}_{24} \mathrm{H}_{52} \mathrm{NaO}_{2} \mathrm{Si}_{2}, 451.3404$.

(ent-15): oil, $[\alpha]_{\mathrm{D}}-6.6\left(c 1 ; \mathrm{CHCl}_{3}\right)$. Physical and spectral data identical to those of $\mathbf{1 5}$. 
$(4 S, 6 R, 7 R, 8 R)-6,8$-Bis(tert-butyldimethylsilyloxy)-5,5,7,9tetramethyldec-1-en-4-ol (16) and $(4 R, 6 R, 7 R, 8 R)-6,8$-bis (tert-butyldimethylsilyloxy)-5,5,7,9-tetramethyldec-1-en-4ol (18). Olefin $15(1.29 \mathrm{~g}, 3 \mathrm{mmol})$ was dissolved in dry $\mathrm{CH}_{2} \mathrm{Cl}_{2}(60 \mathrm{~mL})$ and cooled to $-78^{\circ} \mathrm{C}$. A stream of ozoneoxygen was bubbled through the solution until persistence of the bluish color. Dry $\mathrm{N}_{2}$ was then bubbled through the solution for $10 \mathrm{~min}$. at the same temperature. After addition of $\mathrm{PPh}_{3}(1.18 \mathrm{~g}, 4.5 \mathrm{mmol})$, the solution was left to stir at room temperature for $2 \mathrm{~h}$. Solvent removal under reduced pressure gave a solid material, which was put on the top of a short silica gel pad and rapidly washed with hexane- $\mathrm{Et}_{2} \mathrm{O}$ 99:1. After removal of volatiles under reduced pressure, the crude oily aldehyde was then directly used as such in the next allylation step (for weight calculations, the yield of the ozonolysis step was assumed to be quantitative).

The oily material from above was dissolved under $\mathrm{N}_{2}$ in dry THF $(15 \mathrm{~mL})$ and cooled in an ice bath. After this, a $1 \mathrm{M}$ solution of allylmagnesium bromide in THF ( $4 \mathrm{~mL}, 4 \mathrm{mmol}$ ) was added dropwise, and the mixture was allowed to reach room temperature, followed by stirring for $3 \mathrm{~h}$ (TLC monitoring). The reaction mixture was then poured onto saturated ammonium chloride and extracted several times with $\mathrm{Et}_{2} \mathrm{O}$. The organic layers were then dried over anhydrous $\mathrm{Na}_{2} \mathrm{SO}_{4}$, filtered and evaporated under reduced pressure. The resulting oil was the subjected to a slow and careful chromatography on silica gel (hexane-Et $\left.{ }_{2} \mathrm{O}, 99: 1\right)$ to yield $\mathbf{1 6}(540 \mathrm{mg}, \mathbf{3 8 \%})$ and $\mathbf{1 8}$ (369 $\mathrm{mg}, 26 \%)$.

(16): oil, $[\alpha]_{\mathrm{D}}+5.5\left(\mathrm{c} 1 ; \mathrm{CHCl}_{3}\right)$; IR $v_{\max }\left(\mathrm{cm}^{-1}\right)$ : 3480 (br, OH); ${ }^{1} \mathrm{H}$ NMR $\delta 5.85(1 \mathrm{H}, \mathrm{ddt}, J=17,10.5,7 \mathrm{~Hz}), 5.20-5.15(2 \mathrm{H}, \mathrm{m})$, $3.92(1 \mathrm{H}, \mathrm{d}, J=6 \mathrm{~Hz}), 3.87(1 \mathrm{H}, \mathrm{d}, J=2 \mathrm{~Hz}), 3.65(1 \mathrm{H}, \mathrm{d}, J=10$ $\mathrm{Hz}), 2.44(1 \mathrm{H}, \mathrm{m}), 2.20(1 \mathrm{H}, \mathrm{m}), 2.15-2.05(2 \mathrm{H}, \mathrm{m}), 1.95(1 \mathrm{H}, \mathrm{br}$ s, OH), $1.07(3 \mathrm{H}, \mathrm{d}, J=7 \mathrm{~Hz}), 0.99(3 \mathrm{H}, \mathrm{s}), 0.95(9 \mathrm{H}, \mathrm{s}), 0.94$ $(3 \mathrm{H}, \mathrm{s}), 0.93(9 \mathrm{H}, \mathrm{s}), 0.91(3 \mathrm{H}, \mathrm{d}, J=7 \mathrm{~Hz}), 0.89(3 \mathrm{H}, \mathrm{d}, J=7$ $\mathrm{Hz}), 0.16(3 \mathrm{H}, \mathrm{s}), 0.11(3 \mathrm{H}, \mathrm{s}), 0.10(3 \mathrm{H}, \mathrm{s}), 0.08(3 \mathrm{H}, \mathrm{s}) ;{ }^{13} \mathrm{C}$ NMR $\delta 43.5,18.8,18.6(\mathrm{C}), 136.2,80.7,77.1,75.1,43.4,30.8$ (CH), 118.2, $37.1\left(\mathrm{CH}_{2}\right), 26.5$ (x 3), 26.3 (x 3), 22.0, 21.1, 20.3, $16.8,14.3,-2.2,-3.3,-4.3,-4.4\left(\mathrm{CH}_{3}\right)$; HR ESMS $m / z 495.3667$ $\left(\mathrm{M}+\mathrm{Na}^{+}\right)$, calcd. for $\mathrm{C}_{26} \mathrm{H}_{56} \mathrm{NaO}_{3} \mathrm{Si}_{2}, 495.3666$.

(ent-16): oil, $[\alpha]_{\mathrm{D}}-6.1\left(\mathrm{c} 1 ; \mathrm{CHCl}_{3}\right)$. Physical and spectral data identical to those of $\mathbf{1 6}$.

(18): oil, $[\alpha]_{\mathrm{D}}+23.6\left(\right.$ c $\left.1 ; \mathrm{CHCl}_{3}\right)$; IR $v_{\max }\left(\mathrm{cm}^{-1}\right): 3470(\mathrm{br}, \mathrm{OH})$; ${ }^{1} \mathrm{H}$ NMR $\delta 5.93(1 \mathrm{H}, \mathrm{ddt}, J=17,10.5,7 \mathrm{~Hz}), 5.09(1 \mathrm{H}, \mathrm{dm}, J \sim$ $17 \mathrm{~Hz}), 5.05(1 \mathrm{H}, \mathrm{dm}, J \sim 10.5 \mathrm{~Hz}), 4.35(1 \mathrm{H}, \mathrm{br} \mathrm{s}, \mathrm{OH}), 4.00$ $(1 \mathrm{H}, \mathrm{dd}, J=10,1.5 \mathrm{~Hz}), 3.92(1 \mathrm{H}, \mathrm{d}, J=2 \mathrm{~Hz}), 3.86(1 \mathrm{H}, \mathrm{dd}, J=$ $7.5,1 \mathrm{~Hz}), 2.18(1 \mathrm{H}, \mathrm{m}), 2.10-2.00(3 \mathrm{H}, \mathrm{m}), 1.14(3 \mathrm{H}, \mathrm{d}, J=7$ $\mathrm{Hz}), 1.04(3 \mathrm{H}, \mathrm{s}), 0.92(24 \mathrm{H}, \mathrm{br} \mathrm{s}), 0.88(3 \mathrm{H}, \mathrm{d}, J=7 \mathrm{~Hz}), 0.15$ $(3 \mathrm{H}, \mathrm{s}), 0.13(3 \mathrm{H}, \mathrm{s}), 0.12(3 \mathrm{H}, \mathrm{s}), 0.09(3 \mathrm{H}, \mathrm{s}) ;{ }^{13} \mathrm{C} \mathrm{NMR} \delta 42.6$, 18.8, 18.3 (C), 137.0, 83.7, 78.1, 76.1, 45.0, $31.5(\mathrm{CH}), 116.3$, $36.9\left(\mathrm{CH}_{2}\right), 26.4$ (x 3), 26.2 (x 3), 23.1, 21.8, 20.5, 16.4, 13.7, $-3.0,-3.4,-4.3$ (x 2) $\left(\mathrm{CH}_{3}\right)$; HR ESMS $m / z 495.3666\left(\mathrm{M}+\mathrm{Na}^{+}\right)$, calcd. for $\mathrm{C}_{26} \mathrm{H}_{56} \mathrm{NaO}_{3} \mathrm{Si}_{2}, 495.3666$.

(ent-18): oil, $[\alpha]_{\mathrm{D}}-16.6\left(\right.$ c $\left.1 ; \mathrm{CHCl}_{3}\right)$. Physical and spectral data identical to those of $\mathbf{1 8 .}$

$(4 S, 6 R, 7 R, 8 R)-6,8$-Bis(tert-butyldimethylsilyloxy)-5,5,7,9tetramethyldec-1-en-4-yl acrylate $(17)$ and $(4 R, 6 R, 7 R, 8 R)$ 6,8-bis(tert-butyldimethylsilyloxy)-5,5,7,9-tetramethyldec- 1-en-4-yl acrylate (19). Alcohol 16 or 18 (142 mg, $0.3 \mathrm{mmol})$ was dissolved under $\mathrm{N}_{2}$ in dry $\mathrm{CH}_{2} \mathrm{Cl}_{2}(5 \mathrm{~mL})$, cooled to -78 ${ }^{\circ} \mathrm{C}$ and treated sequentially with ethyl $N, N$-diisopropylamine (160 $\mu \mathrm{L}, 0.9 \mathrm{mmol})$ and acryloyl chloride $(50 \mu \mathrm{L}, 0.6 \mathrm{mmol})$. The reaction mixture was then stirred for $3 \mathrm{~h}$ at $-50^{\circ} \mathrm{C}$. The reaction mixture was then poured onto saturated ammonium chloride and extracted several times with $\mathrm{CH}_{2} \mathrm{Cl}_{2}$. The organic layers were then dried over anhydrous $\mathrm{MgSO}_{4}$, filtered and evaporated under reduced pressure. The resulting oil was the subjected in each case to chromatography on silica gel (hexane$\left.\mathrm{Et}_{2} \mathrm{O}, 98: 2\right)$ to afford, respectively, 17 (130 mg, 82\%) and 19 (130 $\mathrm{mg}, 82 \%$ ), respectively.

(17): oil, $[\alpha]_{\mathrm{D}}+10.9\left(\right.$ c $\left.1 ; \mathrm{CHCl}_{3}\right)$; IR $v_{\max }\left(\mathrm{cm}^{-1}\right)$ : $1727(\mathrm{C}=\mathrm{O})$; ${ }^{1} \mathrm{H}$ NMR $\delta 6.37(1 \mathrm{H}, \mathrm{dd}, J=17.3,1.5 \mathrm{~Hz}), 6.10(1 \mathrm{H}, \mathrm{dd}, J=17.3$, $10.5 \mathrm{~Hz}), 5.80(1 \mathrm{H}, \mathrm{dd}, J=10.5,1.5 \mathrm{~Hz}), 5.74(1 \mathrm{H}, \mathrm{dddd}, J=17$, $10,8,6 \mathrm{~Hz}), 5.30(1 \mathrm{H}, \mathrm{dd}, J=10.5,2.5 \mathrm{~Hz}), 5.03(1 \mathrm{H}, \mathrm{dd}, J=17$, $1.5 \mathrm{~Hz}), 4.98(1 \mathrm{H}, \mathrm{dd}, J=10,1.5 \mathrm{~Hz}), 3.90(1 \mathrm{H}, \mathrm{dd}, J=6.3,1.5$ $\mathrm{Hz}), 3.77(1 \mathrm{H}, \mathrm{d}, J=2.2 \mathrm{~Hz}), 2.68(1 \mathrm{H}, \mathrm{m}), 2.30-2.15(2 \mathrm{H}, \mathrm{m})$, 2.00 (1H, d quint, $J=7.5,2.2 \mathrm{~Hz}), 1.07(3 \mathrm{H}, \mathrm{d}, J=7.5 \mathrm{~Hz}), 1.04$ $(3 \mathrm{H}, \mathrm{s}), 0.99(3 \mathrm{H}, \mathrm{s}), 0.96(9 \mathrm{H}, \mathrm{s}), 0.93(9 \mathrm{H}, \mathrm{s}), 0.92(3 \mathrm{H}, \mathrm{d}, J=7$ $\mathrm{Hz}), 0.90(3 \mathrm{H}, \mathrm{d}, J=7 \mathrm{~Hz}), 0.15(3 \mathrm{H}, \mathrm{s}), 0.13(6 \mathrm{H}, \mathrm{s}), 0.10(3 \mathrm{H}$, s); ${ }^{13} \mathrm{C}$ NMR $\delta 165.7,43.9,18.7,18.6(\mathrm{C}), 135.2,128.8,79.7$, 77.4, 77.1, 43.9, $31.1(\mathrm{CH}), 130.1,117.0,35.8\left(\mathrm{CH}_{2}\right), 26.5$ (x 3), 26.2 (x 3), 22.2, 21.4, 20.4, 17.2, 14.6, -2.5, -3.4, -4.2, -4.3 $\left(\mathrm{CH}_{3}\right)$; HR ESMS $\mathrm{m} / \mathrm{z} 549.3774 \quad\left(\mathrm{M}+\mathrm{Na}^{+}\right)$, calcd. for $\mathrm{C}_{29} \mathrm{H}_{58} \mathrm{NaO}_{3} \mathrm{Si}_{2}, 549.3771$.

(ent-17): oil, $[\alpha]_{\mathrm{D}}-6.3$ (c $\left.1 ; \mathrm{CHCl}_{3}\right)$. Physical and spectral data identical to those of $\mathbf{1 7}$.

(19): oil, $[\alpha]_{\mathrm{D}}+9.1\left(\right.$ c $\left.1 ; \mathrm{CHCl}_{3}\right)$; IR $v_{\max }\left(\mathrm{cm}^{-1}\right): 1728(\mathrm{C}=\mathrm{O}) ;{ }^{1} \mathrm{H}$ NMR $\delta 6.40(1 \mathrm{H}, \mathrm{dd}, J=17.3,1.5 \mathrm{~Hz}), 6.13(1 \mathrm{H}, \mathrm{dd}, J=17.3$, $10.5 \mathrm{~Hz}), 5.81(1 \mathrm{H}, \mathrm{dd}, J=10.5,1.5 \mathrm{~Hz}), 5.72(1 \mathrm{H}, \mathrm{ddt}, J=17$, $10,7 \mathrm{~Hz}), 5.21(1 \mathrm{H}, \mathrm{dd}, J=10,2.5 \mathrm{~Hz}), 5.03(1 \mathrm{H}, \mathrm{dd}, J=17,1.5$ $\mathrm{Hz}), 4.99(1 \mathrm{H}, \mathrm{dd}, J=10,1.5 \mathrm{~Hz}), 4.05(1 \mathrm{H}, \mathrm{d}, J=5 \mathrm{~Hz}), 3.63$ $(1 \mathrm{H}, \mathrm{d}, J=1.5 \mathrm{~Hz}), 2.34(1 \mathrm{H}$, hept, $J=7 \mathrm{~Hz}), 2.30-2.20(2 \mathrm{H}, \mathrm{m})$, $1.92(1 \mathrm{H}, \mathrm{m}), 1.13(3 \mathrm{H}, \mathrm{d}, J=7.5 \mathrm{~Hz}), 1.03(3 \mathrm{H}, \mathrm{s}), 0.97(3 \mathrm{H}, \mathrm{s})$, $0.96(9 \mathrm{H}, \mathrm{s}), 0.94(9 \mathrm{H}, \mathrm{s}), 0.89(3 \mathrm{H}, \mathrm{d}, J=7 \mathrm{~Hz}), 0.88(3 \mathrm{H}, \mathrm{d}, J=$ $7 \mathrm{~Hz}), 0.17(3 \mathrm{H}, \mathrm{s}), 0.16(3 \mathrm{H}, \mathrm{s}), 0.15(3 \mathrm{H}, \mathrm{s}), 0.11(3 \mathrm{H}, \mathrm{s}) ;{ }^{13} \mathrm{C}$ NMR $\delta 165.7,43.7,19.0,18.4$ (C), 134.3, 128.8, 81.5, 76.9, 75.7, 42.9, $30.4(\mathrm{CH}), 130.3,117.5,34.8\left(\mathrm{CH}_{2}\right), 26.6$ (x 3), 26.1 (x 3), $22.9,22.6,20.1,17.2,14.8,-1.9,-3.7,-4.3,-4.7\left(\mathrm{CH}_{3}\right)$; HR ESMS $m / z 549.3774\left(\mathrm{M}+\mathrm{Na}^{+}\right)$, calcd. for $\mathrm{C}_{29} \mathrm{H}_{58} \mathrm{NaO}_{3} \mathrm{Si}_{2}$, 549.3771 .

(ent-19): oil, $[\alpha]_{\mathrm{D}}-8.1$ ( c $1 ; \mathrm{CHCl}_{3}$ ). Physical and spectral data identical to those of $\mathbf{1 9}$.

(6S)-[(3R,4R,5R)-3,5-Bis(tert-butyldimethylsilyloxy)-2,4,6trimethylheptan-2-yl]-5,6-dihydro-2H-pyran-2-one (20) and $\quad(6 R)-[(3 R, 4 R, 5 R)-3,5$-bis(tert-butyldimethylsilyloxy)2,4,6-trimethylheptan-2-yl]-5,6-dihydro-2H-pyran-2-one

(21). Diolefin 17 or 19 (105 mg, $0.2 \mathrm{mmol})$ was dissolved under $\mathrm{N}_{2}$ in dry, degassed toluene $(20 \mathrm{~mL})$ and treated with ruthenium catalyst Ru-I (16 mg, ca. $0.02 \mathrm{mmol}$ ). The mixture was heated at reflux until consumption of the starting material (ca. $4 \mathrm{~h}$, TLC monitoring!). Removal of volatiles under reduced pressure and column chromatography of the residue on silica gel (hexane- $\mathrm{Et}_{2} \mathrm{O}$ 9:1) furnished the desired metathesis products 20 (94 mg, 94\%) and 21 (98 mg, 98\%), 
respectively.

(20): off-white solid, mp $134-135^{\circ} \mathrm{C}$ (from $\mathrm{Et}_{2} \mathrm{O}-\mathrm{CH}_{2} \mathrm{Cl}_{2}$ ), $[\alpha]_{\mathrm{D}}$ -30.5 (c 1; $\left.\mathrm{CHCl}_{3}\right) ; \mathrm{IR} v_{\max }\left(\mathrm{cm}^{-1}\right): 1731(\mathrm{C}=\mathrm{O}) ;{ }^{1} \mathrm{H}$ NMR $\delta 6.92$ $(1 \mathrm{H}, \mathrm{ddd}, J=9.5,6.3,2.2 \mathrm{~Hz}), 6.01(1 \mathrm{H}, \mathrm{dd}, J=9.5,2 \mathrm{~Hz}), 4.55$ $(1 \mathrm{H}, \mathrm{dd}, J=12.2,4 \mathrm{~Hz}), 3.90(1 \mathrm{H}, \mathrm{d}, J=2.5 \mathrm{~Hz}), 3.80(1 \mathrm{H}, \mathrm{dd}, J$ $=5.5,1 \mathrm{~Hz}), 2.50-2.35(2 \mathrm{H}, \mathrm{m}), 2.20(1 \mathrm{H}$, br quint, $J \sim 7 \mathrm{~Hz})$, $2.05(1 \mathrm{H}, \mathrm{m}), 1.12(3 \mathrm{H}, \mathrm{s}), 1.08(3 \mathrm{H}, \mathrm{d}, J=7 \mathrm{~Hz}), 1.00(3 \mathrm{H}, \mathrm{s})$, $0.93(9 \mathrm{H}, \mathrm{s}), 0.90(9 \mathrm{H}, \mathrm{s}), 0.89(3 \mathrm{H}, \mathrm{d}, J=7 \mathrm{~Hz}), 0.88(3 \mathrm{H}, \mathrm{d}, J=$ $7 \mathrm{~Hz}), 0.14(3 \mathrm{H}, \mathrm{s}), 0.09(3 \mathrm{H}, \mathrm{s}), 0.04(3 \mathrm{H}, \mathrm{s}), 0.02(3 \mathrm{H}, \mathrm{s}) ;{ }^{13} \mathrm{C}$ NMR $\delta 164.4,42.8,18.8,18.5$ (C), 145.6, 121.3, 82.3, 79.3, 77.1, 43.4, 30.9 (CH), 26.4 (x 3), 26.1 (x 3), 25.5, 22.1, 21.8, 19.8, 17.2, 14.4, -2.4, -3.5, -4.3, -4.4 ( $\left(\mathrm{CH}_{3}\right)$; HR ESMS $m / z 521.3451$ $\left(\mathrm{M}+\mathrm{Na}^{+}\right)$, calcd. for $\mathrm{C}_{27} \mathrm{H}_{54} \mathrm{NaO}_{4} \mathrm{Si}_{2}, 521.3458$.

(ent-20): oil, $[\alpha]_{\mathrm{D}}+31.1$ ( $c$ 1; $\left.\mathrm{CHCl}_{3}\right)$. Physical and spectral data identical to those of $\mathbf{2 0}$.

The stereostructures of $\mathbf{2 0}$ and ent-20 have been secured by means of an X-ray diffraction analysis. ${ }^{24}$

(21): oil, $[\alpha]_{\mathrm{D}}+16.8\left(\right.$ c $\left.1 ; \mathrm{CHCl}_{3}\right)$; IR $v_{\max }\left(\mathrm{cm}^{-1}\right): 1737(\mathrm{C}=\mathrm{O})$; ${ }^{1} \mathrm{H}$ NMR $\delta 6.89(1 \mathrm{H}, \mathrm{ddd}, J=9.5,6.5,2 \mathrm{~Hz}), 5.98(1 \mathrm{H}, \mathrm{dd}, J=$ 9.5, $2 \mathrm{~Hz}), 4.45(1 \mathrm{H}, \mathrm{dd}, J=13,3.5 \mathrm{~Hz}), 4.09(1 \mathrm{H}, \mathrm{d}, J=2.5 \mathrm{~Hz})$, $3.88(1 \mathrm{H}, \mathrm{dd}, J=5.5,1 \mathrm{~Hz}), 2.33(1 \mathrm{H}, \mathrm{ddt}, J=18,13,2.5 \mathrm{~Hz})$, 2.25-2.15 (2H, m), $1.93(1 \mathrm{H}, \mathrm{m}), 1.08(3 \mathrm{H}, \mathrm{d}, J=7.5 \mathrm{~Hz}), 1.02$ $(3 \mathrm{H}, \mathrm{s}), 0.92(3 \mathrm{H}, \mathrm{s}), 0.89(9 \mathrm{H}, \mathrm{s}), 0.86(9 \mathrm{H}, \mathrm{s}$, overlapping two methyl doublets), $0.12(3 \mathrm{H}, \mathrm{s}), 0.05(3 \mathrm{H}, \mathrm{s}), 0.03(3 \mathrm{H}, \mathrm{s}), 0.005 \mathrm{t}$ $(3 \mathrm{H}, \mathrm{s}),{ }^{13} \mathrm{C}$ NMR $\delta 164.4,42.7,18.8,18.4(\mathrm{C}), 145.6,121.2$, 80.6, 76.8, 76.3, 43.5, 30.6 (CH), 26.4 (x 3), 26.1 (x 3), 24.0, $22.2,19.7,18.6,17.0,14.4,-2.3,-3.6,-4.5,-4.8\left(\mathrm{CH}_{3}\right)$; HR ESMS $m / z 521.3456\left(\mathrm{M}+\mathrm{Na}^{+}\right)$, calcd. for $\mathrm{C}_{27} \mathrm{H}_{54} \mathrm{NaO}_{4} \mathrm{Si}_{2}$, 521.3458 .

(ent-21): oil, $[\alpha]_{\mathrm{D}}-18.2\left(c 1 ; \mathrm{CHCl}_{3}\right)$. Physical and spectral data identical to those of $\mathbf{2 1}$.

$(3 S, 5 R, 6 R, 7 R)-5,7-b i s($ tert-Butyldimethylsilyloxy)-4,4,6,8tetramethylnon-1-en-3-ol (24) and $(3 R, 5 R, 6 R, 7 R)-5,7-$ bis(tert-butyldimethylsilyloxy)-4,4,6,8-tetramethylnon-1-

en-3-ol (26). Olefin 15 was subjected to the same sequence of ozonolysis followed by addition of vinylmagnesium chloride performed with 6. Work-up and careful chromatography on silica gel (hexane- $\left.\mathrm{Et}_{2} \mathrm{O}, 99: 1\right)$ afforded $24(26 \%)$ and $\mathbf{2 6}(24 \%)$.

(24): oil, $[\alpha]_{\mathrm{D}}-15\left(\mathrm{c} 1 ; \mathrm{CHCl}_{3}\right)$; IR $v_{\max }\left(\mathrm{cm}^{-1}\right): 3460$ (br, $\left.\mathrm{OH}\right)$; ${ }^{1} \mathrm{H}$ NMR $\delta 5.95(1 \mathrm{H}, \mathrm{ddd}, J=17,10,6.5 \mathrm{~Hz}), 5.26(1 \mathrm{H}, \mathrm{br} \mathrm{dt}, J \sim$ $17,1.5 \mathrm{~Hz}), 5.20(1 \mathrm{H}, \mathrm{br} \mathrm{dt}, J \sim 10,1.5 \mathrm{~Hz}), 4.14(1 \mathrm{H}, \mathrm{dt}, J=6.5$, $1.5 \mathrm{~Hz}), 4.01(1 \mathrm{H}, \mathrm{d}, J=2.5 \mathrm{~Hz}), 3.89(1 \mathrm{H}, \mathrm{dd}, J=10,1.5 \mathrm{~Hz})$, $2.50(1 \mathrm{H}, \mathrm{br} \mathrm{s}, \mathrm{OH}), 2.10(2 \mathrm{H}, \mathrm{m}), 1.05(3 \mathrm{H}, \mathrm{d}, J=7 \mathrm{~Hz}), 0.99$ $(3 \mathrm{H}, \mathrm{s}), 0.94(9 \mathrm{H}, \mathrm{s}), 0.93(9 \mathrm{H}, \mathrm{s}$, overlapping a methyl doublet), $0.90(3 \mathrm{H}, \mathrm{s}), 0.89(3 \mathrm{H}, \mathrm{d}, J=7 \mathrm{~Hz}), 0.17(3 \mathrm{H}, \mathrm{s}), 0.14(6 \mathrm{H}, \mathrm{s})$, $0.09(3 \mathrm{H}, \mathrm{s}) ;{ }^{13} \mathrm{C}$ NMR $\delta 43.4,18.7,18.6(\mathrm{C}), 138.0,80.3,79.6$, 77.8, 44.7, $31.3(\mathrm{CH}), 116.7\left(\mathrm{CH}_{2}\right), 26.3$ (x 6), 21.1, 21.0, 19.9, 16.6, 13.8, -2.5, -3.0, -4.3 (x 2) $\left(\mathrm{CH}_{3}\right)$; HR ESMS m/z 481.3513 $\left(\mathrm{M}+\mathrm{Na}^{+}\right)$, calcd. for $\mathrm{C}_{25} \mathrm{H}_{54} \mathrm{NaO}_{3} \mathrm{Si}_{2}, 481.3509$.

(ent-24): oil, $[\alpha]_{\mathrm{D}}+19.3\left(c 1 ; \mathrm{CHCl}_{3}\right)$. Physical and spectral data identical to those of $\mathbf{2 4}$.

(26): oil, $[\alpha]_{\mathrm{D}}+8.9\left(\mathrm{c} 1 ; \mathrm{CHCl}_{3}\right) ; \mathrm{IR} v_{\max }\left(\mathrm{cm}^{-1}\right): 3450$ (br, OH); ${ }^{1} \mathrm{H}$ NMR $\delta 5.84(1 \mathrm{H}$, ddd, $J=17,10.5,6.5 \mathrm{~Hz}), 5.26(1 \mathrm{H}$, br ddd, $J \sim 17,2,1.5 \mathrm{~Hz}), 5.15(1 \mathrm{H}$, br ddd, $J \sim 10,2,1.5 \mathrm{~Hz}), 4.70(1 \mathrm{H}$, br s, OH), $4.46(1 \mathrm{H}, \mathrm{d}, J=6.5 \mathrm{~Hz}), 4.01(1 \mathrm{H}, \mathrm{d}, J=2.2 \mathrm{~Hz}), 3.87$
$(1 \mathrm{H}, \mathrm{dd}, J=8.2,1.5 \mathrm{~Hz}), 2.08(1 \mathrm{H}, \mathrm{d}$ quint, $J=8,2 \mathrm{~Hz}), 2.02$ $(1 \mathrm{H}, \mathrm{d}$ quint, $J=7,1.5 \mathrm{~Hz}), 1.16(3 \mathrm{H}, \mathrm{d}, J=7.5 \mathrm{~Hz}), 1.04(3 \mathrm{H}, \mathrm{s})$, $0.95(3 \mathrm{H}, \mathrm{d}, J=7 \mathrm{~Hz}), 0.94(9 \mathrm{H}, \mathrm{s}), 0.93(9 \mathrm{H}, \mathrm{s}), 0.91(3 \mathrm{H}, \mathrm{s})$, $0.90(3 \mathrm{H}, \mathrm{d}, J=7 \mathrm{~Hz}), 0.16(3 \mathrm{H}, \mathrm{s}), 0.15(3 \mathrm{H}, \mathrm{s}), 0.14(3 \mathrm{H}, \mathrm{s})$, $0.10(3 \mathrm{H}, \mathrm{s}) ;{ }^{13} \mathrm{C}$ NMR $\delta 42.3,18.8,18.3(\mathrm{C}), 137.9,83.1,78.5$, 78.2, 45.3, 31.6 (CH), $116.6\left(\mathrm{CH}_{2}\right), 26.4$ (x 3), 26.1 (x 3), 23.2, $22.2,20.2,16.3,13.3,-2.8,-3.4,-4.3,-4.4\left(\mathrm{CH}_{3}\right)$; HR ESMS $m / z 481.3506\left(\mathrm{M}+\mathrm{Na}^{+}\right)$, calcd. for $\mathrm{C}_{25} \mathrm{H}_{54} \mathrm{NaO}_{3} \mathrm{Si}_{2}, 481.3509$.

(ent-26): oil, $[\alpha]_{\mathrm{D}}-8.1\left(\right.$ ( $\left.1 ; \mathrm{CHCl}_{3}\right)$. Physical and spectral data identical to those of $\mathbf{2 6}$.

$(3 S, 5 R, 6 R, 7 R)-5,7-B i s(t e r t-b u t y l d i m e t h y l s i l y l o x y)-4,4,6,8-$ tetramethylnon-1-en-3-yl acrylate $(25)$ and $(3 R, 5 R, 6 R, 7 R)$ 5,7-bis(tert-butyldimethylsilyloxy)-4,4,6,8-tetramethylnon1-en-3-yl acrylate (27). Alcohol 24 or 26 were subjected to esterification with acryloyl chloride under the same conditions as for the preparation of $\mathbf{1 7}$ and $\mathbf{1 9}$. Work-up and column chromatography on silica gel (hexane- $\left.\mathrm{Et}_{2} \mathrm{O}, 98: 2\right)$ furnished respectively, $\mathbf{2 5}(85 \%)$ and $\mathbf{2 7}(83 \%)$.

(25): oil, $[\alpha]_{\mathrm{D}}-14.2\left(\right.$ c $\left.1 ; \mathrm{CHCl}_{3}\right)$; IR $v_{\max }\left(\mathrm{cm}^{-1}\right): 1732(\mathrm{C}=\mathrm{O})$; ${ }^{1} \mathrm{H}$ NMR $\delta 6.40(1 \mathrm{H}, \mathrm{dd}, J=17.3,1.5 \mathrm{~Hz}), 6.14(1 \mathrm{H}, \mathrm{dd}, J=17.3$, $10.5 \mathrm{~Hz}), 5.92(1 \mathrm{H}$, ddd, $J=17.3,10.5,6.2 \mathrm{~Hz}), 5.82(1 \mathrm{H}, \mathrm{dd}, J=$ $10.5,1.5 \mathrm{~Hz}), 5.43(1 \mathrm{H}, \mathrm{d}, J=6.2 \mathrm{~Hz}), 5.30-5.20(2 \mathrm{H}, \mathrm{m}), 3.93$ $(1 \mathrm{H}, \mathrm{d}, J=5.5 \mathrm{~Hz}), 3.78(1 \mathrm{H}, \mathrm{d}, J=2 \mathrm{~Hz}), 2.25(1 \mathrm{H}$, hept, $J=7$ $\mathrm{Hz}), 1.93(1 \mathrm{H}, \mathrm{m}), 1.06(3 \mathrm{H}, \mathrm{d}, J=7 \mathrm{~Hz}), 1.05(3 \mathrm{H}, \mathrm{s}), 1.00(3 \mathrm{H}$, s), $0.96(9 \mathrm{H}, \mathrm{s}), 0.92(9 \mathrm{H}, \mathrm{s}), 0.91(3 \mathrm{H}, \mathrm{d}, J=7 \mathrm{~Hz}), 0.89(3 \mathrm{H}, \mathrm{d}$, $J=7 \mathrm{~Hz}), 0.15(3 \mathrm{H}, \mathrm{s}), 0.13(3 \mathrm{H}, \mathrm{s}), 0.12(3 \mathrm{H}, \mathrm{s}), 0.10(3 \mathrm{H}, \mathrm{s})$; ${ }^{13} \mathrm{C}$ NMR $\delta 164.9,43.3,18.9,18.5(\mathrm{C}), 133.7,128.7,79.7,78.9$, 76.7, 43.4, $30.9(\mathrm{CH}), 130.3,118.2\left(\mathrm{CH}_{2}\right), 26.5$ (x 3), 26.2 (x 3), 22.0 (x 2), 20.1, 17.3, 14.7, -2.2,-3.6, -4.2, -4.4 $\left(\mathrm{CH}_{3}\right)$; HR ESMS $m / z 535.3618\left(\mathrm{M}+\mathrm{Na}^{+}\right)$, calcd. for $\mathrm{C}_{28} \mathrm{H}_{56} \mathrm{NaO}_{4} \mathrm{Si}_{2}$, 535.3615 .

(ent-25): oil, $[\alpha]_{\mathrm{D}}+13.3\left(\right.$ c $\left.1 ; \mathrm{CHCl}_{3}\right)$. Physical and spectral data identical to those of $\mathbf{2 5}$.

(27): oil, $[\alpha]_{\mathrm{D}}+26.5\left(\right.$ c $\left.1 ; \mathrm{CHCl}_{3}\right)$; IR $v_{\max }\left(\mathrm{cm}^{-1}\right): 1731(\mathrm{C}=\mathrm{O})$; ${ }^{1} \mathrm{H}$ NMR $\delta 6.38(1 \mathrm{H}, \mathrm{dd}, J=17.3,1.5 \mathrm{~Hz}), 6.15(1 \mathrm{H}, \mathrm{dd}, J=17.3$, $10.5 \mathrm{~Hz}), 5.83(1 \mathrm{H}, \mathrm{dd}, J=10.5,1.5 \mathrm{~Hz}), 5.77(1 \mathrm{H}, \mathrm{ddd}, J=17.3$, $10.5,6.2 \mathrm{~Hz}), 5.37(1 \mathrm{H}, \mathrm{d}, J=6.2 \mathrm{~Hz}), 5.30-5.20(2 \mathrm{H}, \mathrm{m}), 3.97$ $(1 \mathrm{H}, \mathrm{d}, J=6 \mathrm{~Hz}), 3.70(1 \mathrm{H}, \mathrm{d}, J=2 \mathrm{~Hz}), 2.28(1 \mathrm{H}$, hept, $J=7$ $\mathrm{Hz}), 2.00(1 \mathrm{H}, \mathrm{m}), 1.09(3 \mathrm{H}, \mathrm{d}, J=7 \mathrm{~Hz}), 1.04(3 \mathrm{H}, \mathrm{s}), 0.99(3 \mathrm{H}$, s), $0.96(9 \mathrm{H}, \mathrm{s}), 0.93(9 \mathrm{H}, \mathrm{s}), 0.90(3 \mathrm{H}, \mathrm{d}, J=7 \mathrm{~Hz}), 0.89(3 \mathrm{H}, \mathrm{d}$, $J=7 \mathrm{~Hz}), 0.13(6 \mathrm{H}, \mathrm{s}), 0.11(3 \mathrm{H}, \mathrm{s}), 0.06(3 \mathrm{H}, \mathrm{s}) ;{ }^{13} \mathrm{C} \mathrm{NMR} \delta$ 165.3, 43.3, 19.0, 18.5 (C), 132.9, 128.9, 79.4, 78.7, 76.2, 43.5, $30.5(\mathrm{CH}), 130.4,119.1\left(\mathrm{CH}_{2}\right), 26.6$ (x 3), 26.1 (x 3), 22.6, 21.6, $19.4,17.2,14.5,-2.2,-3.5,-4.5,-4.8\left(\mathrm{CH}_{3}\right)$; HR ESMS $\mathrm{m} / \mathrm{z}$ $535.3613\left(\mathrm{M}+\mathrm{Na}^{+}\right)$, calcd. for $\mathrm{C}_{28} \mathrm{H}_{56} \mathrm{NaO}_{4} \mathrm{Si}_{2}, 535.3615$.

(ent-27): oil, $[\alpha]_{\mathrm{D}}-28.4$ ( c $1 ; \mathrm{CHCl}_{3}$ ). Physical and spectral data identical to those of 27.

The stereostructure of ent-27 has been secured by means of an Xray diffraction analysis. ${ }^{24}$

$(5 S)$ - $[(3 R, 4 R, 5 R)-3,5$-Bis (tert-butyldimethylsilyloxy)-2,4,6trimethylheptan-2-yl]furan-2(5H)-one (28) and (5R)$[(3 R, 4 R, 5 R)-3,5-B i s(t e r t-b u t y l d i m e t h y l s i l y l o x y)-2,4,6-$ trimethylheptan-2-yl]furan-2(5H)-one (29). Diolefin 25 or 27 (102 mg, $0.2 \mathrm{mmol}$ ) was dissolved under $\mathrm{N}_{2}$ in dry, degassed toluene $(25 \mathrm{~mL})$ and treated with Hoveyda-Grubbs 
ruthenium catalyst Ru-III (12 $\mathrm{mg}$, ca. $0.02 \mathrm{mmol}$ ). The mixture was heated at $80^{\circ} \mathrm{C}$ until consumption of the starting material (ca. $4 \mathrm{~h}$, TLC monitoring!). Removal of volatiles under reduced pressure and column chromatography of the residue on silica gel (hexane- $\mathrm{Et}_{2} \mathrm{O}$ 9:1) furnished the desired metathesis products 28 (75 $\mathrm{mg}, 78 \%)$ and 29 (77 $\mathrm{mg}, 80 \%)$, respectively.

(28): oil, $[\alpha]_{\mathrm{D}}-42\left(c 1 ; \mathrm{CHCl}_{3}\right) ; \mathrm{IR} v_{\max }\left(\mathrm{cm}^{-1}\right): 1763(\mathrm{C}=\mathrm{O}) ;{ }^{1} \mathrm{H}$ NMR $\delta 7.62(1 \mathrm{H}, \mathrm{dd}, J=6,1.5 \mathrm{~Hz}), 6.12(1 \mathrm{H}, \mathrm{dd}, J=6,2 \mathrm{~Hz})$, $5.25(1 \mathrm{H}, \mathrm{dd}, J=2,1.5 \mathrm{~Hz}), 3.95(1 \mathrm{H}, \mathrm{d}, J=2.5 \mathrm{~Hz}), 3.80(1 \mathrm{H}$, dd, $J=7.5,2 \mathrm{~Hz}), 2.08(2 \mathrm{H}, \mathrm{m}), 1.08(3 \mathrm{H}, \mathrm{d}, J=7.5 \mathrm{~Hz}), 1.05$ $(3 \mathrm{H}, \mathrm{s}), 0.95(3 \mathrm{H}, \mathrm{d}, J=7 \mathrm{~Hz}), 0.93(9 \mathrm{H}, \mathrm{s}), 0.92(9 \mathrm{H}, \mathrm{s}), 0.94$ $(3 \mathrm{H}, \mathrm{s}), 0.90(3 \mathrm{H}, \mathrm{d}, J=7 \mathrm{~Hz}), 0.15(3 \mathrm{H}, \mathrm{s}), 0.11(3 \mathrm{H}, \mathrm{s}), 0.10$ $(3 \mathrm{H}, \mathrm{s}), 0.07(3 \mathrm{H}, \mathrm{s}) ;{ }^{13} \mathrm{C}$ NMR $\delta 173.1,44.7,18.7,18.5(\mathrm{C})$, $155.8,121.8,87.7,78.3,77.8,45.3,31.5(\mathrm{CH}), 26.3(\mathrm{x} 3), 26.2(\mathrm{x}$ 3), 22.4, 20.3 (x 2), 16.8, 13.8, -2.8, -3.1, -4.3, -4.4 $\left(\mathrm{CH}_{3}\right)$; HR ESMS $m / z 507.3296\left(\mathrm{M}+\mathrm{Na}^{+}\right)$, calcd. for $\mathrm{C}_{26} \mathrm{H}_{52} \mathrm{NaO}_{4} \mathrm{Si}_{2}$, 507.3302 .

(ent-28): oil, $[\alpha]_{\mathrm{D}}+44.5\left(c 1 ; \mathrm{CHCl}_{3}\right)$. Physical and spectral data identical to those of $\mathbf{2 8}$.

(29): oil, $[\alpha]_{\mathrm{D}}+34.5\left(\right.$ c $\left.1 ; \mathrm{CHCl}_{3}\right)$; IR $v_{\max }\left(\mathrm{cm}^{-1}\right): 1763(\mathrm{C}=\mathrm{O})$; ${ }^{1} \mathrm{H}$ NMR $\delta 7.46(1 \mathrm{H}, \mathrm{dd}, J=6,1.5 \mathrm{~Hz}), 6.15(1 \mathrm{H}, \mathrm{dd}, J=6,2.2$ $\mathrm{Hz}), 5.10(1 \mathrm{H}, \mathrm{dd}, J=2.2,1.5 \mathrm{~Hz}), 4.14(1 \mathrm{H}, \mathrm{d}, J=2.5 \mathrm{~Hz}), 3.80$ $(1 \mathrm{H}, \mathrm{dd}, J=7,1.5 \mathrm{~Hz}), 2.13(1 \mathrm{H}, \mathrm{d}$ quint, $J=7,1.5 \mathrm{~Hz}), 1.98$ $(1 \mathrm{H}, \mathrm{d}$ quint, $J=7.5,2.5 \mathrm{~Hz}), 1.09(3 \mathrm{H}, \mathrm{s}), 1.07(3 \mathrm{H}, \mathrm{d}, J=7.5$ $\mathrm{Hz}), 0.92(3 \mathrm{H}, \mathrm{d}, J=7 \mathrm{~Hz}), 0.91(9 \mathrm{H}, \mathrm{s}), 0.90(9 \mathrm{H}, \mathrm{s}), 0.89(3 \mathrm{H}$, d, $J=7 \mathrm{~Hz}), 0.82(3 \mathrm{H}, \mathrm{s}), 0.17(3 \mathrm{H}, \mathrm{s}), 0.13(3 \mathrm{H}, \mathrm{s}), 0.12(3 \mathrm{H}, \mathrm{s})$, $0.05(3 \mathrm{H}, \mathrm{s}) ;{ }^{13} \mathrm{C}$ NMR $\delta 173.0,44.4,18.8,18.7$ (C), 155.0, 123.1, 87.8, 77.5, 77.0, 45.0, $31.5(\mathrm{CH}), 26.5$ (x 3), 26.4 (x 3), $21.2,20.2,18.1,17.2,14.1,-2.6,-3.1,-4.1,-4.3\left(\mathrm{CH}_{3}\right)$; HR ESMS $m / z 507.3304\left(\mathrm{M}+\mathrm{Na}^{+}\right)$, calcd. for $\mathrm{C}_{26} \mathrm{H}_{52} \mathrm{NaO}_{4} \mathrm{Si}_{2}$, 507.3302 .

(ent-29): oil, $[\alpha]_{\mathrm{D}}-36.6\left(\right.$ c $\left.1 ; \mathrm{CHCl}_{3}\right)$. Physical and spectral data identical to those of 29.

\section{Biological procedures}

\section{Cell culture}

Cell culture media were purchased from Gibco (Grand Island, NY, USA). Fetal bovine serum (FBS) was a product of HarlanSeralab (Belton, U.K.). Supplements and other chemicals not listed in this section were obtained from Sigma Chemicals Co. (St. Louis, Mo., USA). Plastics for cell culture were supplied by Thermo Scientific ${ }^{\mathrm{TM}}$ BioLite. All tested compounds were dissolved in DMSO at a concentration of $10 \mu \mathrm{g} / \mathrm{mL}$ and stored at $-20^{\circ} \mathrm{C}$ until use.

Cell lines were maintained in Dulbecco's modified Eagle's medium (DMEM) containing glucose $(1 \mathrm{~g} / \mathrm{L})$, glutamine $(2 \mathrm{mM})$, penicillin $(50 \mathrm{U} / \mathrm{mL})$, streptomycin $(50 \mu \mathrm{g} / \mathrm{mL})$ and amphotericin B $(1.25 \mu \mathrm{g} / \mathrm{mL})$, supplemented with $10 \%$ FBS.

\section{Cytotoxicity assays}

The 3-(4,5-dimethylthiazol-2-yl)-2,5-diphenyltetrazolium bromide (MTT; Sigma Chemical Co., St. Louis, MO) dye reduction assay in 96-well microplates was used, as previously described. ${ }^{25}$ Some $5 \times 10^{3}$ cells of HT-29, HTC-116, MCF-7 and HL-60 and $2.5 \times 10^{3}$ cells of HEK-293 and Hela cells in a total volume of $100 \mu \mathrm{L}$ of their respective growth media were incubated with serial dilutions of the tested compounds. After 2 days of incubation $\left(37{ }^{\circ} \mathrm{C}, 5 \% \mathrm{CO}_{2}\right.$ in a humid atmosphere), $10 \mu \mathrm{l}$ of MTT $(5 \mathrm{mg} / \mathrm{ml}$ in PBS) were added to each well and the plate was incubated for further $4 \mathrm{~h}\left(37^{\circ} \mathrm{C}\right)$. The resulting formazan was dissolved in $150 \mu \mathrm{L}$ of $0.04 \mathrm{~N} \mathrm{HCl} / 2$-propanol and read at 550 $\mathrm{nm}$. All determinations were carried out in triplicate.

\section{Tubulin polymerization}

Tubulin polymerization was carried out in a 96 well plate. In each well $50 \mu \mathrm{L}$ of a solution of $25 \mu \mathrm{M}$ of tubulin in GAB buffer was added to $50 \mu \mathrm{L}$ of $27.5 \mu \mathrm{M}$ solution of the corresponding compounds in GAB buffer $(20 \mathrm{mM}$ sodium phosphate, $10 \mathrm{mM}$ $\mathrm{MgCl}_{2}, 1 \mathrm{mM}$ EGTA, $30 \%$ glycerol) and $0.1 \mathrm{mM}$ GTP at $\mathrm{pH}=$ 6.5. Then, the plate was incubated at $37{ }^{\circ} \mathrm{C}$ in Multiskan (R) and absorbance at $340 \mathrm{nM}$ was registered every 30 seconds during 2 hours.

\section{ELISA analysis}

HT-29 cells at $70-80 \%$ confluence were collected and $1.5 \times 10^{5}$ cells were placed in a six well plate in $1.5 \mathrm{~mL}$ of medium. After $24 \mathrm{~h}$, cells were incubated with the corresponding compounds for $72 \mathrm{~h}$. Culture supernatants were collected and VEGF secreted by HT-29 cells was determined using Invitrogen Human Vascular Endothelial Growth Factor ELISA Kit according to the manufacturer's instructions.

\section{RT-qPCR analysis}

HT-29 cells at 70-80\% confluence were collected and $1.5 \times 10^{5}$ cells were placed in a six well plate in $1.5 \mathrm{~mL}$ of medium. After $24 \mathrm{~h}$, cells were incubated with the corresponding compounds for $72 \mathrm{~h}$. Cells were collected and the total cellular RNA from HT-29 cells was isolated using Ambion RNA extraction Kit according to the manufacturer's instructions. The cDNA was synthesized by MMLV-RT with 1-21 $\mu \mathrm{g}$ of extracted RNA and oligo(dT)15 according to the manufacturer's instructions.

Genes were amplified by use of a thermal cycler and StepOnePlus TM Taqman ${ }^{\circledR}$ probes. TaqMan ${ }^{\circledR}$ Gene Expression Master Mix Fast containing the appropriate buffer for the amplification conditions, dNTPs, thermostable DNA polymerase enzyme and a passive reference probe was used. To amplify each of the genes the predesigned primers were used and sold by Life Technologies TaqMan ${ }^{\circledR}$ Gene Expression Assays, Hs99999903m1 ( $\beta$-actin), Hs00900055-m1 (VEGF), Hs00972646-m1 (hTERT) y Hs00153408-m1 (c-Myc).

\section{Acknowledgments}

Financial support has been granted to M. C. by the Spanish Government (Ministerio de Economía y Competitividad of Spain, project CTQ2014-52949-P), by the Consellería d'Empresa, Universitat i Ciencia de la Generalitat Valenciana (project PROMETEO/2013/027) and by the University Jaume I (project P1·1B2015-75). The authors further thank Prof. P. M. Pihko for fruitful discussions.

\section{References}

1 D. Hanahan and R. A. Weinberg, Cell, 2011, 144, 646-674.

2 F. Torres-Andón and B. Fadeel, Acc. Chem. Res., 2013, 46, 733-742.

3 T. Fojo (Ed.), The Role of Microtubules in Cell Biology, Neurobiology and Oncology, Humana Press, Totowa, NJ, 2008.

4 G. M. Alushin, G. C. Lander, E. H. Kellogg, R. Zhang, D. Baker, E. Nogales, Cell, 2014, 157, 1117-1129.

5 (a) T. Beckers and S. Mahboobi, Drugs Fut., 2003, 28, 767-785. (b) J. A. Hadfield, S. Ducki, N. Hirst and A. T. McGown, Progr. Cell Cycle Res., 2003, 5, 309-325. (c) M. A. Jordan and L. Wilson, Nat. 
Rev. Cancer, 2004, 4, 253-265. (d) S.-H. Chen and J. Hong, Drugs Fut., 2006, 31, 123-150. (e) E. Pasquier and M. Kavallaris, IUBMB Life, 2008, 60, 165-170. (f) P. Singh, K. Rathinasamy, R. Mohan and D. Panda, IUBMB Life, 2008, 60, 368-375. (g) P. G. Morris and M. N. Fornier, Clin. Cancer Res., 2008, 14, 7167-7172. (h) E. A. Perez, Mol. Cancer Ther., 2009, 8, 2086-2095. (i) S. M. Chen, L.-H. Meng and J. Ding, Expert Opin. Invest. Drugs, 2010, 19, 329-343. (j) D. Calligaris, P. Verdier-Pinard, F. Devred, C. Villard, D. Braguer and D. Lafitte, Cell. Mol. Life Sci., 2010, 67, 1089-1104.

6 (a) K.-H. Altmann and J. Gertsch, Nat. Prod. Rep., 2007, 24, $327-$ 357. (b) D. G. I. Kingston, J. Nat. Prod., 2009, 72, 507-515.

7 J. Chen, T. Liu, X. Dong and Y. Hu, Mini-Rev. Med. Chem., 2009, 9, 1174-1190.

8 Y. Fu, S. Li, Y. Zu, G. Yang, Z. Yang, M. Luo, S. Jiang, M. Wink and T. Efferth, Curr. Med. Chem., 2009, 16, 3966-3985.

9 F. Sarabia, M. García-Castro and A. Sánchez-Ruiz, Curr. Bioact. Comp., 2006, 2, 269-299.

10 T. Usui, H. Watanabe, H. Nakayama, Y. Tada, N. Kanoh, M. Kondoh, T. Asao, K. Takio, H. Watanabe, K. Nishikawa, T. Kitahara and H. Osada, Chem. \& Biol., 2004, 11, 799-806.

11 (a) K. Yasui, Y. Tamura, K. Nakatani, K. Kawada and M. Ohtani, J. Org. Chem., 1995, 60, 7567-7574. (b) M. K. Gurjar, J. T. Henri, Jr., D. S. Bose and A. V. R. Rao, Tetrahedron Lett., 1996, 37, 66156618. (c) N. Chida, M. Yoshinaga, T. Tobe and S. Ogawa, Chem. Comm., 1997, 1043-1044. (d) H. Watanabe, H. Watanabe, M. Bando, M. Kido and T. Kitahara, Tetrahedron, 1999, 55, 9755-9776. (e) G. E. Keck, C. E. Knutson and S. A. Wiles, Org. Lett., 2001, 3, 707-710. (f) L. C. Dias, L. G. de Oliveira and M. A. de Sousa, Org. Lett., 2003, 5, 265-268. (g) X. Shen, A. S. Wasmuth, J. Zhao, C. Zhu and S. G. Nelson, J. Am. Chem. Soc., 2006, 128, 7438-7439. (h) D. Enders, S. Dhulut, D. Steinbusch and A. Herrbach, Chem. Eur. J., 2007, 13, 3942-3949. (i) C. Bressy, J.-P. Vors, S. Hillebrand, S. Arseniyadis and J. Cossy, Angew. Chem. Int. Ed., 2008, 47, 10137-10140. (j) M. T. Crimmins and A.-M. R. Dechert, Org. Lett., 2009, 11, 1635-1638.

12 For two comprehensive, recent reviews, see: (a) J. A. Marco, M. Carda, J. Murga and E. Falomir, Tetrahedron, 2007, 63, 2929-2958. (b) J. A. Marco and M. Carda, Recent advances in the field of naturally occurring 5,6-dihydropyran-2-ones, in Natural Lactones and Lactams. Synthesis, Occurrence and Biological Activity, T. Janecki (Ed.), Wiley-VCH, 2014, pp. 51-100. For pironetin tubulin binding site: (a) J. Yang, Y. Wang, T. Wang, J. Jiang, C. H. Botting, H. Liu, Q. Chen, J. Yang, J. H. Naismith, X. Zun and L. Chen, Nature Communicantions, 2016, 7, doi:10.1038/ncomms12103. (b) A. E Prota,. J. Setter, A. B Waight, K. Bargsten, J. Murga, J. F. Diaz and M. O. Steinmetz, Journal of Molecular Biology, 2016, doi: 10.1016/j.jmb.2016.06.023.

13 J. A. Marco, J. García-Pla, M. Carda, J. Murga, E. Falomir, C. Trigili, S. Notararigo, J. F. Díaz and I. Barasoain, Eur. J. Med. Chem., 2011, 46, 1630-1637.

14 J. Paños, S. Díaz-Oltra, M. Sánchez-Peris, J. García-Pla, J. Murga, E. Falomir, M. Carda, M. Redondo-Horcajo, J. F. Díaz, I. Barasoain and J. A. Marco, Org. Biomol. Chem. 2013, 11, 5809-5826.

15 R. W. Hoffmann, Chem. Rev., 1989, 89, 1841-1860.

16 For two interesting reviews on the conformational aspects of openchain carbon backbones, see: (a) R. W. Hoffmann, M. Stahl, U. Schopfer and G. Frenking, Chem. Eur. J., 1998, 4, 559-566. (b) R. W. Hoffmann, Angew. Chem. Int. Ed., 2000, 39, 2054-2070.

17 J. Welti, S. Loges, S. Dimmeler and P. Carmeliet, J. Clin. Invest. 2013, 123, 3190-3200.

18 C. Yinnan and Z. Yanmin Z., Pharmacol. Ther., 2016, 163, 24-47.

19 (a) H. Huang, H. Weng, H. Zhou and L. Qu, Curr. Pharm. Des., 2014, 20, 6543-6554. (b) B.-J. Chen, Y.-L. Wu, Y. Tanaka and W. Zhang, Int. J. Biol. Sci., 2014, 10, 1084-1096.

20 This corresponds to the concept of polypharmacology: J.-U. Peters, J. Med. Chem. 2013, 56, 8955-8971.

21 S. Källström, A. Erkkilä, P. M. Pihko, R. Sjöholm, R. Sillanpää and R. Leino, Synlett, 2005, 751-756. In order to work efficiently at a much higher scale than in the original paper, the experimental procedure had to be carried out as described in the Experimental.

22 For recent reviews on metathesis, see: (a) J. Cossy, S. Arseniyadis and C. Meyer (Eds.), Metathesis in Natural Product Synthesis,
Wiley-VCH, Weinheim, 2010. (b) A. H. Hoveyda, J. Org. Chem., 2014, 79, 4763-4792.

23 In some cases, products from intramolecular Michael addition of one hydroxyl group in the side chain to the conjugated $\mathrm{C}=\mathrm{C}$ bond were detected.

24 The crystal structures have been deposited at the Cambridge Crystallographic Data Centre and allocated the following deposition numbers: 2 (CCDC-1431101), ent-2 (CCDC-1431108), 4 (CCDC1431102), ent-4 (CCDC-1431106), 5 (CCDC-1431104), ent-5 (CCDC-1431105), 20 (CCDC-1431103), ent-20 (CCDC-1431107) and ent-27 (CCDC-1431109).

25 S. Rodríguez-Nieto, M. A. Medina and A. R. Quesada, Anticancer Res. 2001, 21, 3457-3460. 